Prepared in cooperation with the Keweenaw Bay Indian Community

\title{
Water Quality and Hydrology of the Yellow Dog and Salmon Trout Watersheds, Marquette County, Michigan, 2013-16
}

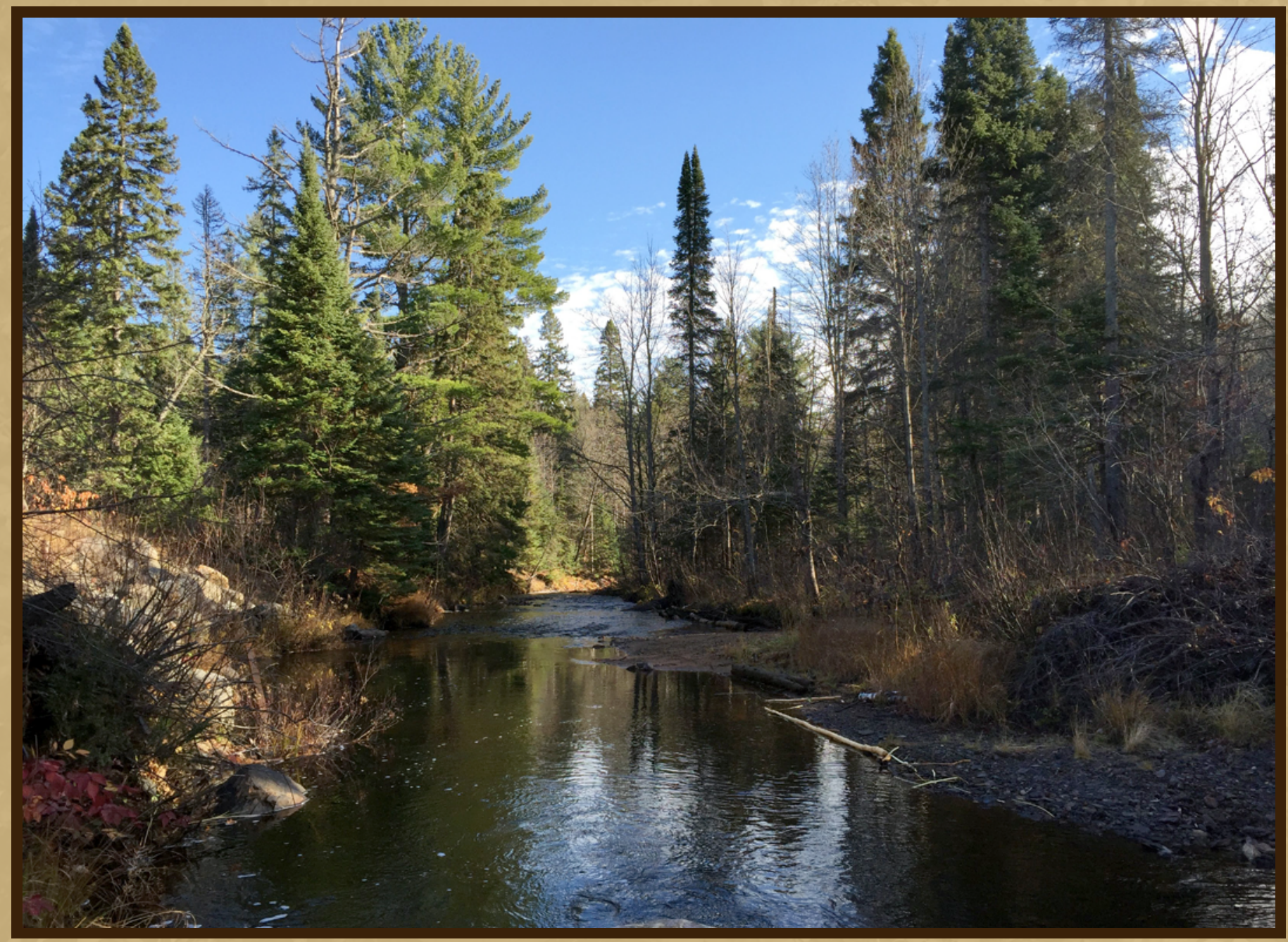

Scientific Investigations Report 2018-5152 
Front cover photograph. Yellow Dog River near Big Bay, Michigan, streamgage (U.S. Geological Survey station 04044375).

Back cover photograph. Salmon Trout Watershed view to the North, in the direction of Lake Superior. 


\section{Water Quality and Hydrology of the Yellow Dog and Salmon Trout Watersheds, Marquette County, Michigan, 2013-16}

By Christopher J. Hoard and Thomas L. Weaver

Prepared in cooperation with the Keweenaw Bay Indian Community

Scientific Investigations Report 2018-5152 


\title{
U.S. Department of the Interior \\ DAVID BERNHARDT, Acting Secretary
}

\author{
U.S. Geological Survey \\ James F. Reilly II, Director
}

U.S. Geological Survey, Reston, Virginia: 2019

For more information on the USGS - the Federal source for science about the Earth, its natural and living resources, natural hazards, and the environment-visit https://www.usgs.gov or call 1-888-ASK-USGS (1-888-275-8747).

For an overview of USGS information products, including maps, imagery, and publications, visit https://store.usgs.gov.

Any use of trade, firm, or product names is for descriptive purposes only and does not imply endorsement by the U.S. Government.

Although this information product, for the most part, is in the public domain, it also may contain copyrighted materials as noted in the text. Permission to reproduce copyrighted items must be secured from the copyright owner.

Suggested citation:

Hoard, C.J., and Weaver, T.L., 2019, Water quality and hydrology of the Yellow Dog and Salmon Trout watersheds, Marquette County, Michigan, 2013-16: U.S. Geological Survey Scientific Investigations Report 2018-5152, 24 p., https://doi.org/10.3133/sir20185152.

ISSN 2328-0328 (online) 


\section{Acknowledgments}

Special thanks are extended to Chauncey Moran, known to locals as the "Yellow Dog Riverkeeper." Special thanks as well to Environmental Department staff at Keweenaw Bay Indian Community, including Chuck Brumleve and Lori Ann Sherman, and to staff at Great Lakes Indian Fish \& Wildlife Commission, including Ann McCammon Soltis and John Coleman. Chauncey, Chuck, and John initially guided the team into the remote area and helped establish the final list of sampling stations. Special thanks are also extended to Warren C. Swartz, Jr. and the Keweenaw Bay Indian Community Tribal Council. Without the commitment of the Keweenaw Bay Indian Community, this study would not have been possible.

The Upper Midwest Water Science Center Escanaba Field Office was responsible for nearly all the field work during the study. Under the able leadership of Neal Craig, long days of work were endured by Matt Holmio, Dean Burdett, and Joe Clark. Although the working conditions included swarms of black flies, mosquitoes, gnats, and ticks and weather that ranged from cold with chest-deep snow to very hot and wet, the team did an outstanding job of collecting waterquality samples. 



\section{Contents}

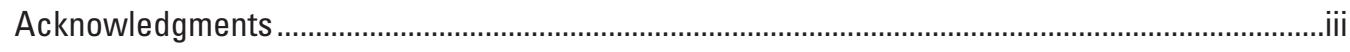

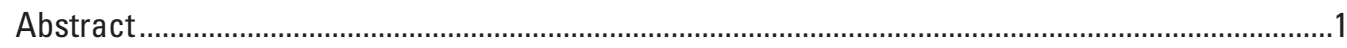

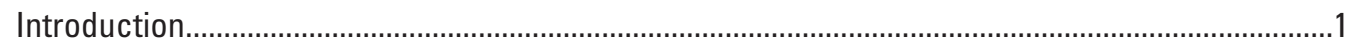

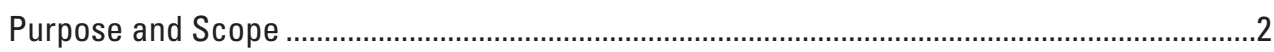

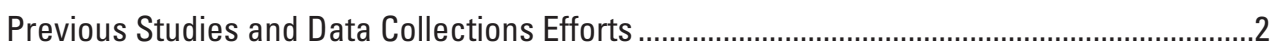

Description of the Study Area ...........................................................................................

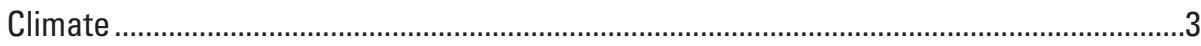

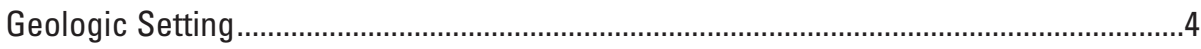

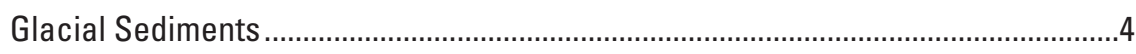

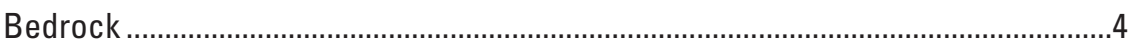

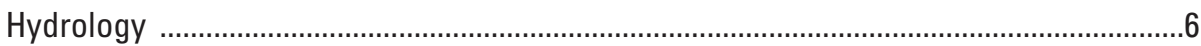

Yellow Dog River ........................................................................................................

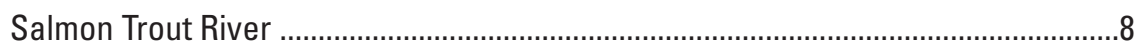

Tributary to Salmon Trout River ...................................................................................

Tributary to East Branch Salmon Trout River ..........................................................

East Branch Salmon Trout River.............................................................................

Methods of Data Collection and Analysis .............................................................................

Flow Measurement........................................................................................................

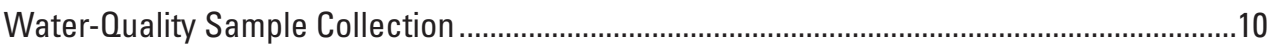

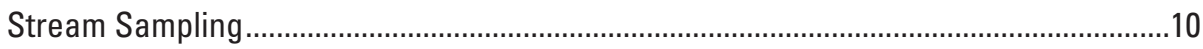

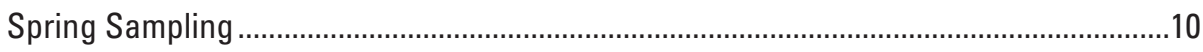

Bed-Sediment Collection....................................................................................................

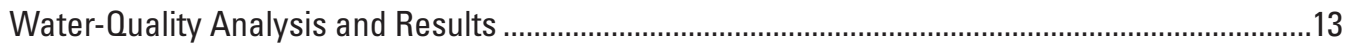

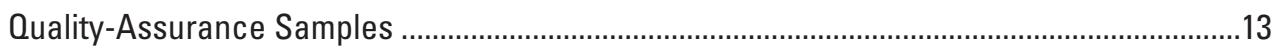

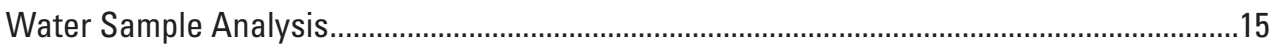

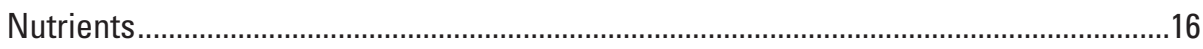

Copper and Nickel ..............................................................................................

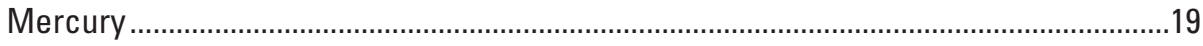

Results of Select Constituents.......................................................................................19

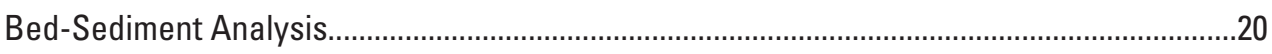

Summary

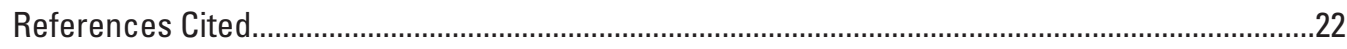




\section{Figures}

1. Map showing location of Yellow Dog and Salmon Trout watersheds and associated water-quality and streamgage stations.

2. Maps showing $A$, Glacial and $B$, bedrock geologic maps of the Yellow Dog and Salmon Trout watersheds.

3. Graphs showing $A$, annual streamflow percentage by flow component and station and $B$, estimated monthly precipitation and evapotranspiration for the Yellow Dog and Salmon Trout watersheds.

4. Photographs showing $A$, spring sampling apparatus and $B$, example of spring sample collection at U.S. Geological Survey station 464545087522801

5. Graph showing distribution of nutrient concentrations sampled in streams and springs in the Yellow Dog and Salmon Trout watersheds, 2013-16.

6. Graphs showing distribution of selected metal concentrations sampled in streams and springs in the Yellow Dog and Salmon Trout watersheds, 2013-16.

7. Graph showing distribution of selected major ion concentrations sampled in streams and springs in the Yellow Dog and Salmon Trout watersheds, 2013-16.

8. Graph showing distribution of bed-sediment concentrations for select metals with associated threshold effect concentration and probable effect concentrations

9. Graph showing distribution of select metal concentrations in bed-sediment samples.

\section{Tables}

1. Climate data from National Oceanic and Atmospheric Administration station 200770 near Big Bay, Michigan, 2013-16

2. Summary of streamflow characteristics for U.S. Geological Survey stations 04043238,04043244 , and 04043275

3. Range of reporting levels used by the U.S. Geological Survey National Water Quality Laboratory for constituents sampled during 2013-16

4. Comparison of replicate samples collected for water-quality constituents

5. Comparison of replicate samples collected for bed-sediment constituents

6. Summary of field blank data collected for water-quality constituents ............................16

7. Consensus-based sediment-quality guidelines for freshwater ecosystems 


\section{Conversion Factors}

U.S. customary units to International System of Units

\begin{tabular}{|c|c|c|}
\hline Multiply & By & To obtain \\
\hline \multicolumn{3}{|c|}{ Length } \\
\hline inch (in.) & 2.54 & centimeter $(\mathrm{cm})$ \\
\hline inch (in.) & 25.4 & millimeter (mm) \\
\hline foot $(\mathrm{ft})$ & 0.3048 & meter $(\mathrm{m})$ \\
\hline mile (mi) & 1.609 & kilometer (km) \\
\hline \multicolumn{3}{|c|}{ Area } \\
\hline square mile $\left(\mathrm{mi}^{2}\right)$ & 2.590 & square kilometer $\left(\mathrm{km}^{2}\right)$ \\
\hline \multicolumn{3}{|c|}{ Volume } \\
\hline gallon (gal & 3.785 & liter $(\mathrm{L})$ \\
\hline gallon (gal & 0.003785 & cubic meter $\left(\mathrm{m}^{3}\right)$ \\
\hline cubic inch $\left(\mathrm{in}^{3}\right)$ & 0.01639 & liter $(\mathrm{L})$ \\
\hline cubic foot $\left(\mathrm{ft}^{3}\right)$ & 28.32 & cubic decimeter $\left(\mathrm{dm}^{3}\right)$ \\
\hline \multicolumn{3}{|c|}{ Flow rate } \\
\hline cubic foot per second $\left(\mathrm{ft}^{3} / \mathrm{s}\right)$ & 0.02832 & cubic meter per second $\left(\mathrm{m}^{3} / \mathrm{s}\right)$ \\
\hline $\begin{array}{l}\text { cubic foot per second per square } \\
\text { mile }\left(\left[\mathrm{ft}^{3} / \mathrm{s}\right] / \mathrm{mi}^{2}\right)\end{array}$ & 0.01093 & $\begin{array}{l}\text { cubic meter per second per square } \\
\text { kilometer }\left(\left[\mathrm{m}^{3} / \mathrm{s}\right] / \mathrm{km}^{2}\right)\end{array}$ \\
\hline \multicolumn{3}{|c|}{ Mass } \\
\hline ounce, avoirdupois (oz) & 28.35 & gram $(\mathrm{g})$ \\
\hline pound, avoirdupois (lb) & 0.4536 & kilogram (kg) \\
\hline
\end{tabular}

Temperature in degrees Celsius $\left({ }^{\circ} \mathrm{C}\right)$ may be converted to degrees Fahrenheit $\left({ }^{\circ} \mathrm{F}\right)$ as follows:

$$
{ }^{\circ} \mathrm{F}=\left(1.8 \times{ }^{\circ} \mathrm{C}\right)+32 .
$$

Temperature in degrees Fahrenheit $\left({ }^{\circ} \mathrm{F}\right)$ may be converted to degrees Celsius $\left({ }^{\circ} \mathrm{C}\right)$ as follows:

$$
{ }^{\circ} \mathrm{C}=\left({ }^{\circ} \mathrm{F}-32\right) / 1.8 \text {. }
$$

\section{Datum}

Vertical coordinate information is referenced to the North American Vertical Datum of 1988 (NAVD 88).

Horizontal coordinate information is referenced to the North American Datum of 1983 (NAD 83).

Elevation, as used in this report, refers to distance above the vertical datum. 


\title{
Supplemental Information
}

Concentrations of chemical constituents in water are given in either milligrams per liter (mg/L) or micrograms per liter $(\mu \mathrm{g} / \mathrm{L})$.

Concentrations of chemical constituents in sediment are given in either milligrams per kilogram $(\mathrm{mg} / \mathrm{kg})$ or micrograms per kilogram $(\mu \mathrm{g} / \mathrm{kg})$.

\section{Abbreviations}

\author{
ADCP acoustic Doppler current profiler \\ ADV acoustic Doppler velocimeter \\ AMV aquatic maximum value \\ FCV final chronic value \\ NOAA National Oceanic and Atmospheric Administration \\ NWIS National Water Information System \\ NWOL National Water Quality Laboratory \\ PEC probable effect concentration \\ PVC polyvinyl chloride \\ TEC threshold effect concentration \\ USGS U.S. Geological Survey
}




\title{
Water Quality and Hydrology of the Yellow Dog and Salmon Trout Watersheds, Marquette County, Michigan, 2013-16
}

\author{
By Christopher J. Hoard and Thomas L. Weaver
}

\section{Abstract}

In 2013, the U.S. Geological Survey, in cooperation with the Keweenaw Bay Indian Community, began monitoring the water quality of springs and seeps within the Yellow Dog and Salmon Trout watersheds in Marquette County, Michigan. The objectives of this study were to (1) monitor streamflow and analyze the hydrology of the watersheds and (2) characterize the water quality in the watersheds prior to development of mineral resources within the watershed. Three continuous-record streamgages (U.S. Geological Survey stations 04043238,04043244 , and 04043275 ) were examined to identify runoff and baseflow components of streamflow and the relative magnitudes of those components. Streamflow at each station was dominated by groundwater discharge with about 70 to 80 percent of the annual streamflow being groundwater-derived baseflow.

From May 2013 to October 2016, 239 water-quality samples were collected at 15 stations within the Yellow Dog and Salmon Trout watersheds. Of the 15 stations sampled, 8 of the stations were springs and 7 of the stations were streams. Samples were analyzed for nutrient, trace metal, and majorion species at all stations with additional suspended-sediment samples collected at the 7 stream stations. Where applicable, water-quality results were compared to aquatic health guidelines used by the Michigan Department of Environmental Quality. Copper concentrations exceeded the final chronic value five times and the aquatic maximum value once, whereas silver concentrations exceeded the final chronic value twice and the aquatic maximum value once. Results indicate that chloride concentrations may be increasing at some stations, but values are generally low with a median concentration of 0.25 milligram per liter.

Bed-sediment chemistry was evaluated twice for each stream sampling station. Samples were collected in the first and last year of the study and analyzed for trace metals. Sediment chemistry results were compared to consensus-based sediment quality guidelines. None of the metal constituents analyzed exceeded the threshold effect concentration or probable effect concentration thresholds, indicating a healthy aquatic environment in relation to bed-sediment quality.

\section{Introduction}

The Yellow Dog Plains, which is an area in a remote part of northwestern Marquette County in the Upper Peninsula of Michigan (fig. 1), is a flat, glacial outwash plain composed primarily of sand. The outwash plain serves as an aquifer that supplies numerous seeps and springs that are the headwaters of several streams. Land cover surrounding the Yellow Dog Plains is primarily forest that does not have much human activity other than timber harvesting. In 2010, development began on an underground mine facility for a sulfide deposit bearing nickel, copper, and trace amounts of other minerals. Production quantity mineral extraction at the mine began in September 2014 (Eagle Mine, 2017). The study area within the Yellow Dog and Salmon Trout watersheds (fig. 1) consist of the eastern section of the Yellow Dog Plains where mining activities are taking place.

The Yellow Dog River (fig. 1) originates from a section of the Ottawa National Forest (fig. 1), where the river is designated a Federal Scenic and Wild River (U.S. Department of Agriculture, 2007). The river flows along the southern edge of the Yellow Dog Plains with portions of this watershed in the area that may be affected by mining activities. The Yellow Dog River discharges into Lake Independence near Big Bay on Lake Superior, which discharges into Lake Superior (fig. 1).

Headwaters of the Salmon Trout River (fig. 1) are in the Yellow Dog Plains, primarily downgradient of mining operations (Eagle Mine, 2014). The Salmon Trout River and its numerous tributaries flow north through the Huron Mountains, which are heavily forested, then discharges to Lake Superior at Salmon Trout Bay (fig. 1). The Salmon Trout River is an important ecological habitat for this region, and the reach of the stream near the mouth is home to the last known breeding population of coaster brook trout on Lake Superior's south shore (Newman and DuBois, 1996). The health of Yellow Dog and Salmon Trout watersheds is critical to sustaining the natural habitat of this region. As a result, understanding the current state of the water quality in these watersheds is important to protect this habitat, which supports the coaster brook trout. Developing a baseline understanding of current waterquality and sediment conditions will enable resource managers 


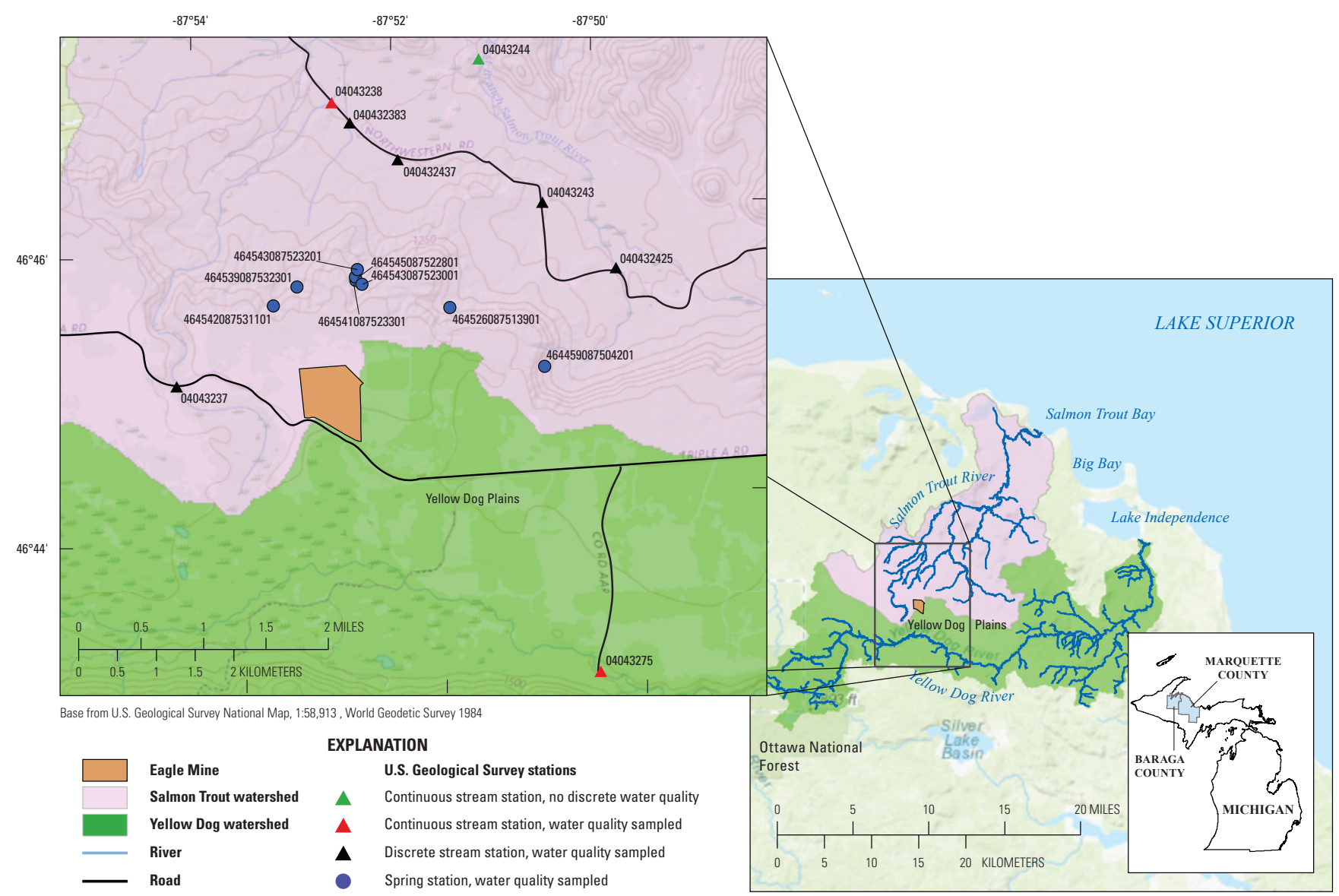

Figure 1. Location of Yellow Dog and Salmon Trout watersheds and associated water-quality and streamgage stations.

a means to assess and address potential harmful changes that may be related to future land use changes and development.

\section{Purpose and Scope}

The purpose of this report is to (1) describe the collection of hydrologic and water-quality data for a portion of the Yellow Dog and Salmon Trout watersheds in Michigan's Upper Peninsula and (2) evaluate the hydrologic and water-quality data of those watersheds. The period of study was from May 2013 to November 2016. Continuous streamflow, water temperature, and specific conductance data were collected at three stations in the study area (fig. 1). Discrete water-quality data were collected 16 times during the study period at 7 stream stations and 8 springs, or seeps, within the two watersheds.

\section{Previous Studies and Data Collections Efforts}

The Yellow Dog and Salmon Trout watersheds have been studied during the past decade for the purposes of assessing baseline water quality. The Yellow Dog Plains have been actively logged for decades but had stayed remote, with limited accessibility until mineral exploration began in earnest in the mid-2000s. To understand the predevelopment hydrology of the watersheds, the U.S. Geological Survey (USGS) installed a continuous-record streamgage and water-quality sonde at one location on the Yellow Dog River, Salmon Trout River, and East Branch Salmon Trout River in December 2004, December 2004, and November 2005, respectively. An assessment of hydrologic information of the Yellow Dog and Salmon Trout watersheds was provided in Mayer and others (2004), although the hydrologic information prior to the construction of the USGS gaging stations is sparse. The Michigan Department of Environmental Quality collected water-quality samples from the Yellow Dog and Salmon Trout Rivers and the adjacent Cedar and Big Pup Rivers in December 2003 (Premo and others, 2005), although that dataset is also sparse.

The Superior Watershed Partnership developed a watershed management plan for the Salmon Trout watershed in 2007. Macroinvertebrate surveys were completed between 2000 and 2005 as part of the management plan at several stream locations in the watershed to provide an indicator of stream health (Superior Watershed Partnership, 2007). The streams, in general, scored in the fair to good range with most in the good range when the surveys were being completed (Superior Watershed Partnership, 2007). 
The Yellow Dog Watershed Preserve began collecting physical water-quality parameters and various chemical constituent concentrations from streams and springs as early as 2004 (Emily Whittaker, Yellow Dog Watershed Preserve, oral commun., 2016). In 2012, the Superior Watershed Partnership set up a Community Environmental Monitoring Program, in cooperation with the Marquette County Community Foundation and Eagle Mine, to monitor the environment around the Eagle Mine, Humboldt Mill, and associated transportation routes (Superior Watershed Partnership, 2007). As part of the Community Environmental Monitoring Program, groundwater and surface-water quality were monitored by analyzing samples for various chemical constituents, with a focus on metals. Most locations monitored were on Eagle Mine property, but some monitoring locations adjacent to the mine property were also included (Superior Watershed Partnership, 2007).

\section{Description of the Study Area}

The Yellow Dog and Salmon Trout watersheds drain 69.6 and 49.4 square miles $\left(\mathrm{mi}^{2}\right)$, respectively. For this study, only the area upstream from Lake Independence is included for the Yellow Dog watershed (fig. 1). The watersheds are primarily in the northwest portion of Marquette County, Michigan (fig. 1) except for a small portion of the Yellow Dog watershed in northeastern Baraga County, Michigan (fig. 1). Land-surface elevation ranges from about 601 feet (ft) where the Salmon Trout River discharges into Lake Superior to $1,905 \mathrm{ft}$ in the southwest portion of the Yellow Dog watershed. Numerous springs and seeps that form the headwaters of most of the branches of the Salmon Trout River are first expressed on the north slope of the Yellow Dog Plains (fig. 1). The exception is the Main Branch Salmon Trout River, which extends upstream and south of the Triple A Road and has its headwaters on the Yellow Dog Plains within 1 mile of, and at about the same elevation as, the Yellow Dog River (fig. 1).
These springs and seeps discharge water derived from the sand-dominated glacial outwash deposits that form the Yellow Dog Plains and are at elevations that range from 1,250 to $1,340 \mathrm{ft}$. The National Land Cover Dataset of 2011 (Homer and others, 2015) indicated that land cover in both watersheds is primarily undeveloped forest and wetlands (92 percent) with lesser amounts of grassland, open water, and developed land. Jack pine, which constitutes most of the trees on the Yellow Dog Plains, seems to have been the dominant species since deglaciation (Brubaker, 1975) even though other similar areas nearby in Marquette County have developed white pine and maple forests as well.

\section{Climate}

Temperature, precipitation, and snowfall data were measured by a National Oceanic and Atmospheric Administration (NOAA) cooperative climate observer 1-mile northwest of Big Bay (NOAA station 200770). All climatic data for 2013-16 were accessed at the National Climate Data Center by Justin Titus (National Oceanic and Atmospheric Administration, written commun., 2018). A NOAA cooperative weather station also is at Eagle Mine; however, data at this station are incomplete (National Oceanic and Atmospheric Administration, 2018). Therefore, for purposes of this study, only the Big Bay dataset has been referenced.

The climate of the Yellow Dog and Salmon Trout River watersheds is typical of the northern Great Lakes Basin. The climate can vary greatly between seasons, with cooler temperatures and greater precipitation occurring inland and especially in higher-elevation areas of the watershed, whereas areas closer to Lake Superior have more moderate temperatures and, typically, less precipitation. Annual precipitation measured as rain and rain-equivalent snowfall at the NOAA cooperative station at Big Bay in 2013-16 was 41.0, 39.7, 28.6, and 39.1 inches, respectively (table 1). Mean-monthly

Table 1. Climate data from National Oceanic and Atmospheric Administration station 200770 near Big Bay, Michigan, 2013-16.

\begin{tabular}{|c|c|c|c|c|c|c|c|c|c|c|c|c|c|}
\hline Year & January & February & March & April & May & June & July & August & September & October & November & December & Annual \\
\hline \multicolumn{14}{|c|}{ Precipitation (inches) } \\
\hline 2013 & 2.49 & 2.38 & 2.03 & 5.46 & 3.93 & 3.72 & 6.33 & 3.29 & 0.97 & 3.92 & 4.19 & 2.32 & 41.0 \\
\hline 2015 & 1.28 & 1.58 & 1.29 & 2.49 & 3.78 & 4.4 & 1.52 & ${ }^{1} 0.73$ & 1.6 & 2.35 & 3.32 & 5.02 & 28.6 \\
\hline 2016 & 2.42 & 3.31 & 2.41 & 3.3 & 2.86 & 2.77 & 3.79 & 4.94 & 5.39 & 2.98 & 1.53 & 3.44 & 39.1 \\
\hline 2013 & 19.8 & 18.1 & 24.6 & 33.8 & 45.8 & 57.2 & 64.4 & 66.5 & 57.6 & 46.8 & 32 & 15.5 & 40.2 \\
\hline 2014 & 8.2 & 9.9 & 17.2 & 34.2 & 49.7 & 58.3 & 64.4 & 61.8 & 57.3 & 44.4 & 27.3 & 24.5 & 38.1 \\
\hline 2015 & 14.5 & 7.0 & 26.2 & 38.8 & 49.7 & 56.5 & 66.5 & ${ }^{1} 66.0$ & 64.1 & 46.1 & 39.4 & 31.6 & 36.1 \\
\hline 2016 & 20.0 & 22.9 & 30.5 & 35.3 & 50.2 & 59.6 & 66.8 & 67.2 & 60.6 & 48.8 & 42.2 & 22.8 & 42.2 \\
\hline
\end{tabular}

${ }^{1}$ Indicates incomplete data for that month. 
temperatures ranged from 7.0 degrees Fahrenheit $\left({ }^{\circ} \mathrm{F}\right)$ during February 2015 to $67.2^{\circ} \mathrm{F}$ during August 2016 (table 1). The mean-annual temperature for the study area is about $41.0^{\circ} \mathrm{F}$. Typically, the northern Upper Peninsula has a freezefree period that ranges from 100 to 140 days. Big Bay has an average freeze-free period of 193 days although the length of this period decreases rapidly away from Lake Superior and as elevation is gained (Justin Titus, National Oceanic and Atmospheric Administration, written commun., 2018).

\section{Geologic Setting}

The land-surface features in northern Marquette County are affected by the underlying Archean and Precambrian bedrock features. Unconsolidated glacial deposits, which overlie the bedrock in most locations, range in thickness from 0 to more than $200 \mathrm{ft}$. Topography of the study area, other than the Yellow Dog Plains, is rugged, especially when compared to nearly all the rest of Michigan. Elevation of the land surface within the study area ranges from about $600 \mathrm{ft}$ at the mouth of the Salmon Trout River to $1,520 \mathrm{ft}$ in the Huron Mountains, which constitute the northern part of the Salmon Trout watershed. The upper Yellow Dog watershed has land-surface elevations of more than 1,900 ft just southwest of the Yellow Dog Plains.

\section{Glacial Sediments}

Overlying bedrock in most places throughout the Yellow Dog and Salmon Trout watersheds is unconsolidated glacial deposits of varying thickness (Farrand and Bell, 1982). The thickness of glacial deposits in most of the study area is less than $50 \mathrm{ft}$, except for the Yellow Dog Plains, the area immediately surrounding Big Bay, and three other small outliers near Lake Superior (Twenter, 1981). The sediments of the Yellow Dog Plains range from $50 \mathrm{ft}$ to greater than $200 \mathrm{ft}$ (Twenter, 1981). Glacial deposits are dominated by materials ranging from coarse-grained sands and outwash to fine-grained tills (fig. 2). Except for areas where bedrock crops out at the land surface, landforms including outwash plains, moraines, and till plains created by Pleistocene glacial advance and retreat (melting) are the predominant geomorphologic features of the present-day Upper Peninsula of Michigan (Farrand and Bell, 1982).

The glacial history of the study area is complex. Based on numerous studies, multiple episodes of Wisconsinan-age glaciation, beginning around 75,000 years ago (Illinois State Geological Survey, 2009), are known to have occurred in the study area. Earlier glacial advances also covered the study area, but glacially derived sediments, which compose most of the present-day unconsolidated deposits overlying bedrock in the study area, are primarily attributed to late Wisconsinan readvances. As the ice advanced from the present-day Lake Superior Basin, it formed into lobes that flowed primarily south and west - the Michigamme lobe covered the study area. The Yellow Dog Plains highland is a sand-dominated outwash plain that was formed during a glacial stillstand, or stagnation, that marked the southernmost, and final, intrusion of the Marquette readvance into the study area about 9,900-10,000 years ago.

The glaciers deposited coarse-grained material in the Yellow Dog Plains that allows for rapid infiltration and interaction between streams and groundwater, whereas the fine-grained material acts as a barrier to groundwater flow resulting in springs and seeps such as the ones that are prevalent on the north slope of the Yellow Dog Plains at an elevation ranging from 1,250 to $1,340 \mathrm{ft}$. These springs and seeps are the headwater area of most of the branches of the Salmon Trout River. Groundwater discharge from unconsolidated glacial deposits sustains streamflow in the Yellow Dog and Salmon Trout Rivers during dry periods of the year.

\section{Bedrock}

The bedrock geology of the Yellow Dog and Salmon Trout River watersheds in northern Marquette County is complex. The age of the Precambrian rock underlying and cropping out in the Upper Peninsula spans about 3 billion years; ages range from some of the oldest known rocks on the North American continent (3.5-2.8 billion years) to some of the youngest in the Lake Superior Basin (the Jacobsville Sandstone of the Keweenawan Supergroup, hereafter referred to as the Jacobsville Sandstone, has been dated variously between 1.1 billion and 540 million years) (Cannon and Simmons, 1973; Van Schmus and Woolsey, 1975; Sims and Peterman, 1983). The area currently (2018) occupied by Lake Superior was rifted apart about 1.1 billion years ago resulting in lava flows as thick as 12,000 meters (39,400 feet) in the basin. Many geologists believe the bedrock north of the Marquette trough consists of separate microcontinents that coalesced and sutured with another continental piece south of the Marquette trough (Cambray, 1978; Hoffman, 1988). The Marquette trough, which contains the economic iron ore deposits of the Marquette Iron Range, is interpreted as the suture zone. Rocks north and south of the Marquette trough are inclined steeply toward the center, where the basins are that contain the iron, and are very different from each other.

Upper parts of the Yellow Dog and Salmon Trout watersheds are underlain by the Michigamme Slate of the Baraga Group of the Marquette Range Supergroup (hereafter referred to as the Michigamme Slate). The Yellow Dog River runs roughly parallel to the formation contact between the Michigamme Slate and older Archean granitic and gneissic rocks (Reed and Daniels, 1987) (fig. 2) whereas branches of the Salmon Trout River run almost perpendicular to the contact between the Michigamme Slate and the Jacobsville Sandstone (Reed and Daniels, 1987). After crossing the Michigamme Slate, the Yellow Dog and Salmon Trout Rivers are underlain by older Archean granites and gneisses and then by younger Jacobsville Sandstone in the last few miles before both rivers flow north into Lake Superior (fig. 2). Unlike the Yellow Dog Plains, unconsolidated sediments are typically not very thick throughout the Salmon Trout River watershed. Nevertheless, bedrock outcrops are present in only a few locations 


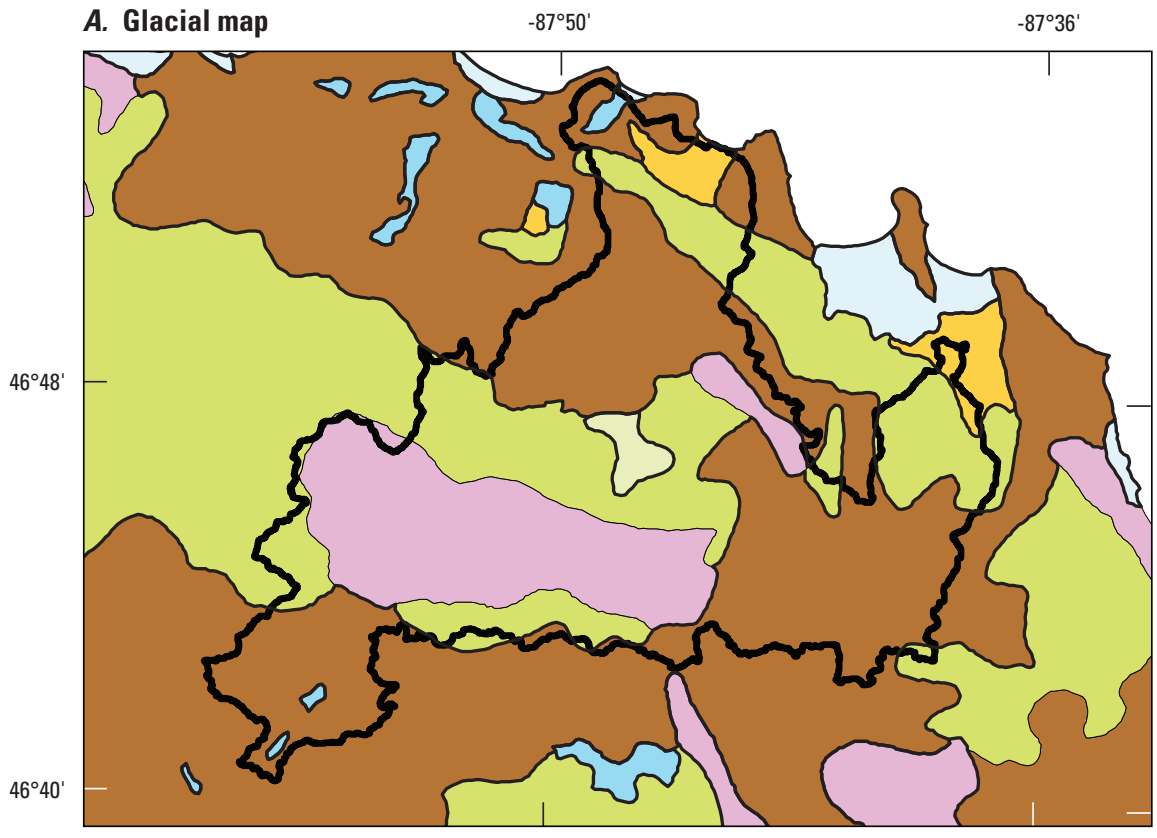

Base modified from Farrand and Bell, 1982, 1:300,000 , World Geodetic Survey 1984
B. Bedrock map

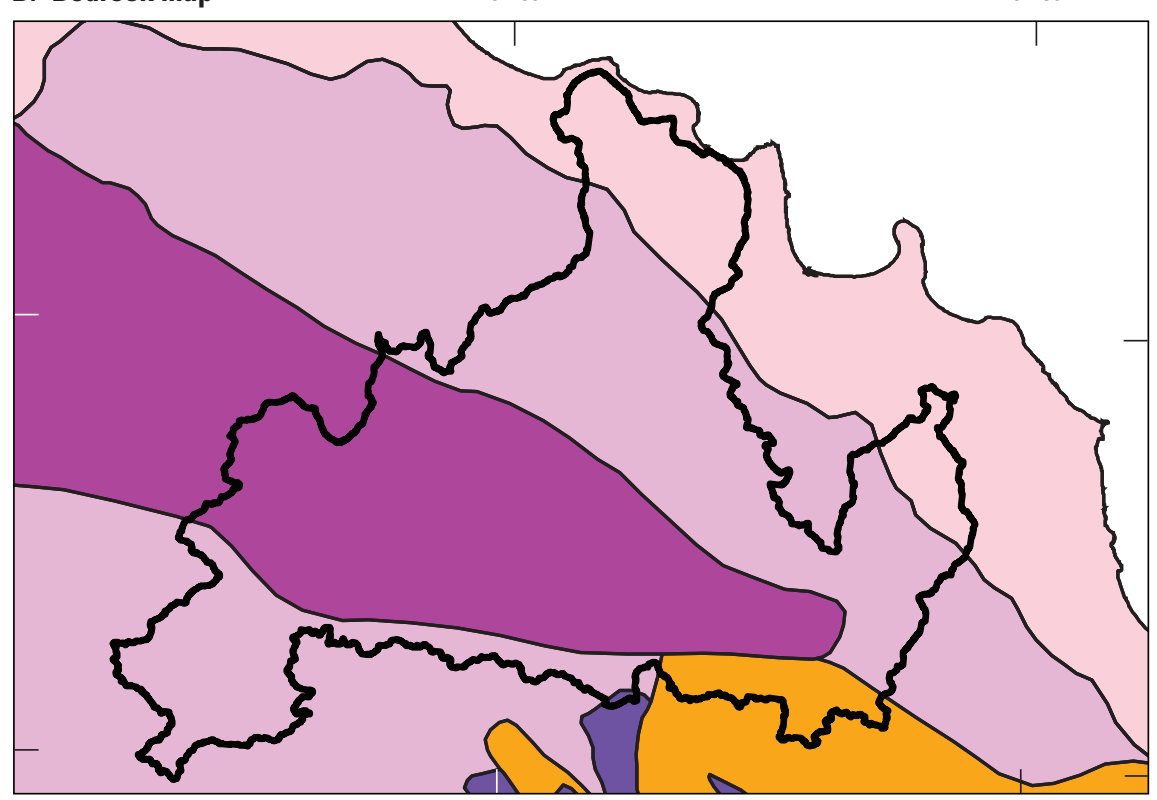

Base modified from Reed and Daniels, 1987, 1:300,000 , World Geodetic Survey 1984

EXPLANATION

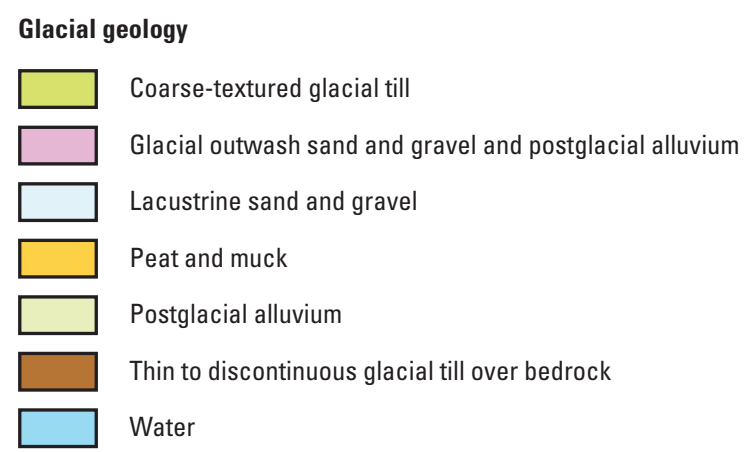

Yellow Dog and Salmon Trout watersheds

Bedrock geology

$\square$ Jacobsville Sandstone

Oak Bluff formation

Michigamme Slate

Archean granitic and gneissic

Archean volcanic and sedimentary

Figure 2. A, Glacial and $B$, bedrock geologic maps of the Yellow Dog and Salmon Trout watersheds. 
within the study area including the rock bluff that is used as the surface entrance to the Eagle Mine. Intruding into the Michigamme Slate are peridotite dikes that include the sulfide deposits being targeted at Eagle Mine and elsewhere in the Upper Peninsula. Mineralization of the dikes probably took place as the dikes intruded through the overlying Michigamme Slate. Except in the Jacobsville Sandstone near Lake Superior, bedrock is likely to contain substantial amounts of water only where it is fractured.

\section{Hydrology}

The hydrology of the Yellow Dog and Salmon Trout watersheds in this study was investigated by measuring streamflow at the seven water-quality sampling stations (fig. 1) and one continuous streamgaging station. At the five discrete stream stations, streamflow was measured during each sampling trip. Streamflow measurements were made on occasion at two of the three continuous stream stations. The three continuous stream stations began operation in December 2005. In April 2017, the Yellow Dog River USGS station 04043275 was deactivated. Annual-mean streamflow and mean-annual runoff are currently (2018) available for each of the three stations. Should loading calculations be required in the future, each water-quality sample has an associated streamflow, obtained either through a measurement or from the stagedischarge relation at the streamgage stations.

Analysis of data from the three continuous-record streamgages indicates differences in the three watersheds. Drainage area, period of record low streamflow, period of record high streamflow, annual-mean streamflow, and meanannual water yield are summarized in table 2 . The watersheds receive similar precipitation, but the streams respond differently. The observed heterogeneity is likely the result of the location of the streams within the study area and geologic setting. Normally, Yellow Dog River, despite its much larger drainage area, has a lower baseflow than either the Main Branch or East Branch Salmon Trout Rivers. Compared to the Yellow Dog River, the East Branch Salmon Trout River period of record low streamflow is nearly three times higher, the period of record peak streamflow is similar, and the annual mean streamflow per mile of drainage basin is nearly twice as high (table 2). The mean-annual runoff of the Main Branch Salmon Trout River is nearly the same as the Yellow Dog River, and the mean-annual runoff for both rivers is only about one-half of the East Branch Salmon Trout River.

Hydrograph separation, the process of deconstructing a streamflow hydrograph into baseflow and runoff components, for USGS stations 04043238, 04043244, and 04043275 was completed using the Groundwater Toolbox software (Barlow and others, 2014). Baseflow estimates obtained using the PART, HYSEP and BFI methods (Barlow and others, 2014) were averaged to compute a mean-annual baseflow estimate for each station. These estimates were calculated from 2005 to 2015 except for USGS station 04043244, which was from 2006 to 2015. Although volume of streamflow varies among the streams, all volumes are similar in that annual baseflow to the streams is typically 70 to 80 percent of the total flow in the stream (fig. $3 A$ ). Baseflow contributions of this magnitude reflect the importance of groundwater discharge to the hydrologic system because discharge is the principle component of baseflow to these streams.

For 2005-15, monthly precipitation and evapotranspiration estimates were downloaded for the Yellow Dog and Salmon Trout watersheds from the USGS Geo Data Portal (https://cida.usgs.gov/gdp/). The watershed boundaries used to represent the Yellow Dog and Salmon Trout watersheds were derived from the National Hydrography Dataset Plus Version 2 catchment data (McKay and others, 2012). The watershed boundaries were then used to extract the precipitation and evapotranspiration estimates from the USGS Geo Data Portal. Estimates of precipitation and evapotranspiration were developed based on data or information from the PRISM Climate Group (2018) and Senay and others (2013), respectively. Plotting monthly precipitation and monthly evapotranspiration shows the relation between the two major inputs and outputs of water to the watersheds (fig. $3 B$ ). During 2005-15, peak evapotranspirative losses occur during the summer, which is typically when precipitation is lower. Much of the precipitation in the study area occurs in the fall and winter so water is

Table 2. Summary of streamflow characteristics for U.S. Geological Survey stations 04043238 , 04043244, and 04043275.

$\left[\mathrm{mi}^{2}\right.$, square mile; $\mathrm{ft}^{3} / \mathrm{s}$, cubic foot per second; $\mathrm{ft}^{3} / \mathrm{s} / \mathrm{mi}^{2}$, cubic foot per second per square mile; >, greater than]

\begin{tabular}{|c|c|c|c|c|c|c|}
\hline Station name & Station number & $\begin{array}{l}\text { Drainage area } \\
\text { at gage }\left(\mathrm{mi}^{2}\right)\end{array}$ & $\begin{array}{l}\text { Period of record } \\
\text { low flow }\left(\mathrm{ft}^{3} / \mathrm{s}\right)\end{array}$ & $\begin{array}{l}\text { Period of record } \\
\text { peak flow }\left(\mathrm{ft}^{3} / \mathrm{s}\right)\end{array}$ & $\begin{array}{l}\text { Annual mean } \\
\text { flow }\left(\mathrm{ft}^{3} / \mathrm{s}\right)\end{array}$ & $\begin{array}{c}\text { Mean annual } \\
\text { water yield } \\
\left(\mathrm{ft}^{3} / \mathrm{s} / \mathrm{mi}^{2}\right)\end{array}$ \\
\hline $\begin{array}{l}\text { Salmon Trout River near Big } \\
\text { Bay, Michigan }\end{array}$ & 04043238 & 6.74 & 2.0 & 76 & 5.96 & 0.88 \\
\hline $\begin{array}{l}\text { East Branch Salmon Trout River } \\
\text { near Dodge City, Michigan }\end{array}$ & 04043244 & 10.2 & 9.5 & 464 & 19.3 & 1.89 \\
\hline
\end{tabular}




\section{A. Percent of annual flow as streamflow component by station}

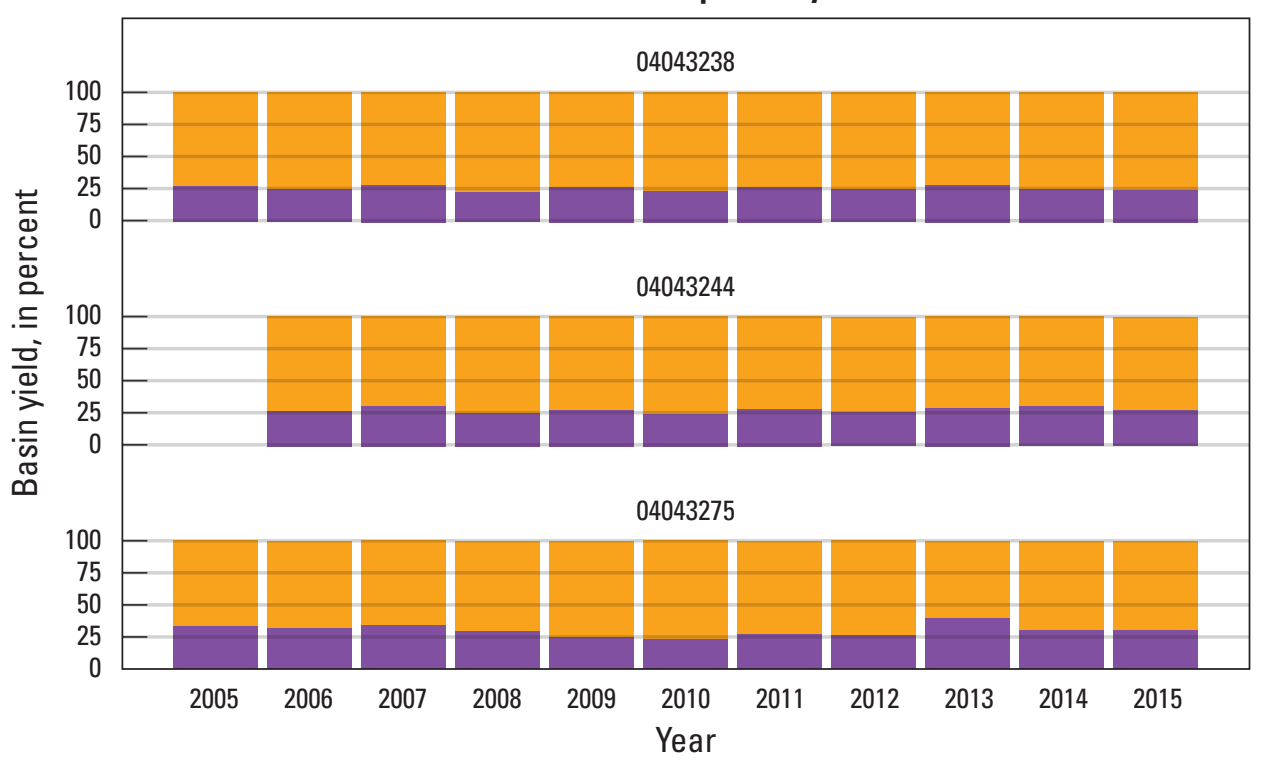

EXPLANATION

Streamflow component

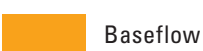

Runoff

\section{B. Estimated precipitation and evapotranspiration in study watersheds}

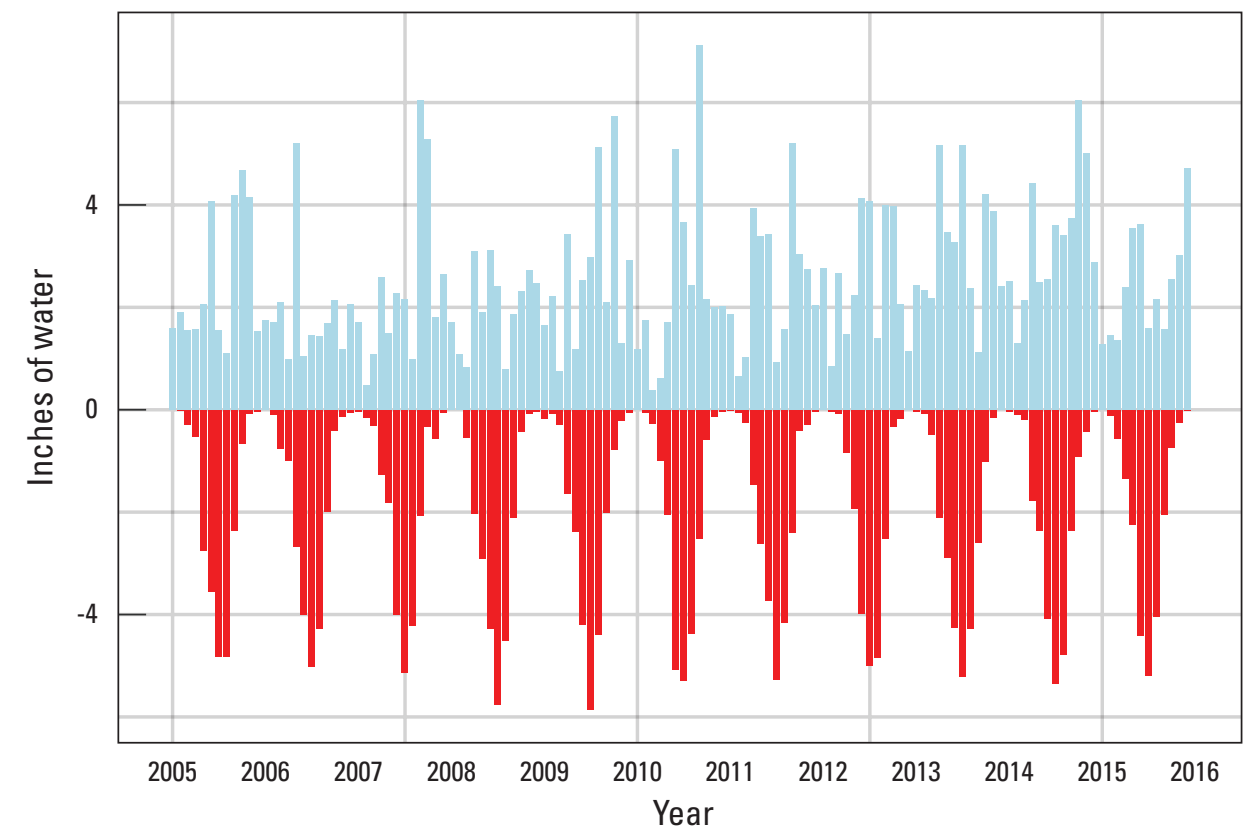

EXPLANATION

Budget component

Evapotranspiration

Precipitation

Figure 3. $A$, annual streamflow percentage by flow component and station and $B$, estimated monthly precipitation and evapotranspiration for the Yellow Dog and Salmon Trout watersheds.

likely going into groundwater storage before being released from storage during the summer.

\section{Yellow Dog River}

The water-quality sampling station on the Yellow Dog River was at the continuous-record streamgage (USGS station 04043275, fig. 1) locally known as Bob Lake Road (fig. 1 map). A timber bridge on the road at this location was destroyed prior to the establishment of the USGS streamgage in December 2004. After the bridge was destroyed, vehicles, including all-terrain vehicles, crossed the stream at a shallow gravel bar about $50 \mathrm{ft}$ downstream. The drainage basin at this station constitutes an area of $31.8 \mathrm{mi}^{2}$. This station is in a channel reach that is high gradient, and is composed primarily of sand, gravel, cobbles, and broken rock. The streamgage along with a water-quality sonde that measures water temperature and specific conductance were installed near the former bridge abutment on the left bank and were made operational in December 2004, running continuously until the station was discontinued in April 2017. Conditions for measuring 
streamflow at this station are generally good, although during high-flow conditions the use of an acoustic Doppler current profiler (ADCP) and pulley system installed several years ago may be required. Unfortunately, depth-integrated, isokinetic, water-quality samples (U.S. Geological Survey, National Field Manual, Chapter A4, section 3) can only be collected at the station when the water is a wadable depth (U.S. Geological Survey, variously dated). An upstream bridge (USGS station 04043270) is available although it is at least 2.5 river miles above the streamgage; the next bridge downstream is at least 5 river miles. During this study, annual runoff exceeded the mean-annual runoff for the period of record (12.9 inches) every year, ranging from 14.3 inches in 2014 to 17.9 inches in 2015. At USGS station 04043270, peak streamflow for the period of record, which was on May 1, 2013, is at least $611 \mathrm{ft}^{3} / \mathrm{s}$. Unfortunately, the streamgage was damaged during that high-flow event, and the peak was extrapolated from a crest-stage gage mark that was exceeded. The lowest streamflow for the period of record is $3.5 \mathrm{ft}^{3} / \mathrm{s}$, which occurred on August 28, 2007.

\section{Salmon Trout River}

An upstream sampling station on the Main Branch Salmon Trout River (USGS station 04043237) was established at the Triple A Road crossing southwest of Eagle Mine (fig. 1). Water-quality samples were typically collected upstream from the corrugated steel culvert at this location. The channel through this reach is composed of silt, sand, gravel, and cobbles, with some broken rock, particularly within the last $15 \mathrm{ft}$ upstream from the culvert, where the rock was brought in as rip-rap. The channel is low gradient near the culvert, except for a rock riffle created by the rip-rap, and the banks are lined with tag alders. The elevation of the stream drops about $350 \mathrm{ft}$ between this location and the continuous-record streamgage at USGS station 04043238 as the stream flows north off the Yellow Dog Plains. Conditions for measuring streamflow and collecting discrete water-quality samples at this station are good for all flow conditions.

A second sampling station on the Main Branch Salmon Trout River was established at the location of the continuousrecord streamgage (USGS station 04043238) just downstream from the Northwestern Road bridge (fig. 1). The drainage basin at this station constitutes an area of $6.74 \mathrm{mi}^{2}$. The channel through the reach at this station is composed of silt, sand, gravel, and cobbles, with some rock. Immediately upstream from the bridge, the channel is lower gradient compared to immediately downstream, where a series of small riffles are present in the first few hundred feet. The streamgage and a water-quality sonde measuring water temperature and specific conductance were installed at this station and were made operational October 28, 2004. Currently (2018), the streamgage and water-quality sonde are still in operation.

Collecting accurate continuous specific conductance data at this station has been problematic. Shortly after gage construction, the downstream control, a very old and large beaver dam, was mostly removed. Removal of the dam led to very shallow and somewhat turbulent gage pool conditions. Fouling conditions of the conductance probe, which was purposely lowered because of the lowered gage pool elevation, became commonplace. In addition, new beaver dam construction, sometimes overnight, has exacerbated sediment fouling of the sonde. Upon removal of the beaver dams, required to maintain integrity of the Northwestern Road bridge, sediment is remobilized and can collect near the sonde. A small tributary that enters the main channel on the upstream right side of the bridge initially caused some heterogeneity in specific conductance readings at the gage. Channel geometry changes at the bridge and removal of the downstream beaver dam seem to have largely eliminated the heterogeneity. Reference gage, crest-stage gage, and sonde deployment at the station were rehabilitated in fall 2017, and the conductance probe seems to have worked satisfactorily since. Conditions for measuring streamflow and collecting discrete water-quality samples at this station are good for all flow conditions. During this study, runoff exceeded the mean-annual runoff for the period of record (12.0 inches) every year, ranging from 12.4 inches in 2016 to 14.2 inches in 2013. The highest streamflow for the period of record is $76 \mathrm{ft}^{3} / \mathrm{s}$, which occurred on April 30, 2013. The lowest streamflow for the period of record is $2.0 \mathrm{ft}^{3} / \mathrm{s}$, which occurred on February 20, 2010.

\section{Tributary to Salmon Trout River}

A sampling station on a tributary to Main Branch Salmon Trout River (USGS station 040432383) was established just off the Northwestern Road. (fig. 1). The stream was typically sampled upstream from the corrugated steel culvert at this location. The channel through this reach is composed of silt, sand, gravel, and cobbles, with exposed red clay banks just upstream from the sampling location. The channel has a moderate gradient near the culvert and is lined with mostly deciduous trees and ferns upstream. The elevation of the stream at this location is several hundred feet lower than at its source spring, although the gradient is low between the sampling station and its confluence with the Salmon Trout River about $1,500 \mathrm{ft}$ north. Conditions for measuring streamflow and collecting discrete water-quality samples at this station are good for all flow conditions.

\section{Tributary to East Branch Salmon Trout River}

The furthest upstream sampling station on a tributary to the East Branch Salmon Trout River (USGS station 040432425) was established just off the Northwestern Road about 9,000 ft west of the fork off the Triple A Road (fig. 1). The stream was typically sampled just upstream from the bridge at this location. In 2004, and for several years after, a large impoundment of water was behind a beaver dam just upstream from this road crossing. After dam removal, the area has undergone a major transformation and currently (2018) is heavily vegetated with grasses and some trees in the low gradient area upstream from the road crossing that was formerly 
flooded. The channel through this reach is composed primarily of silt and sand upstream from the bridge, with more gravel, cobbles, and rocks downstream, where gradient increases rapidly and several riffles are within $100 \mathrm{ft}$ of the bridge. The elevation of the stream has lowered at least $350 \mathrm{ft}$ between its source along the base of the Yellow Dog Plains and this location, although the gradient is low between the sampling station and its confluence with the furthest east branch of the East Branch Salmon Trout River about 2,500 ft downstream. The confluence is a series of cross-connecting channels. Conditions for measuring streamflow and collecting discrete water-quality samples at this station are good for all flow conditions.

A sampling station on a second tributary to the East Branch Salmon Trout River (USGS station 04043243) was established just off the Northwestern Road about 8,000 ft northwest of USGS station 040432425 (fig. 1). The stream was typically sampled upstream from the bridge at this location. The channel through this reach is composed primarily of silt and sand upstream and downstream from the bridge, with sparse gravel, cobbles, and rocks present. The elevation at this station is at least $240 \mathrm{ft}$ lower than at its source along the base of the Yellow Dog Plains, although the gradient is low between the sampling station and the confluence about $2,500 \mathrm{ft}$ downstream, with the furthest east branch of the East Branch Salmon Trout River. The main branch of the stream at the confluence is a series of cross-connecting channels, although this tributary is a single channel leading up to the confluence. Conditions for measuring streamflow and collecting discrete water-quality samples at this station are good for all flow conditions.

A sampling station on the furthest downstream tributary to East Branch Salmon Trout River was at the road crossing on the Northwestern Road (USGS station 040432437, fig. 1). The stream was typically sampled upstream from the bridge at this location. The channel through this reach is composed of silt, sand, gravel, and cobbles, with broken rock serving as rip-rap at the bridge. The channel immediately upstream from the sampling location is primarily sand and its moderately graded banks are lined with deciduous, cedar, and mixed pine trees. Several riffles are immediately downstream from the bridge, but the gradient lessens and becomes much more grown in with tag alders. The elevation of the stream at this point is several hundred feet lower than at its source along the base of the Yellow Dog Plains, although the elevation only lowers about another $50 \mathrm{ft}$ between the sampling station and the confluence with the East Branch Salmon Trout River about 6,000 ft northeast. Conditions for measuring streamflow and collecting discrete water-quality samples at this station are good for all flow conditions.

\section{East Branch Salmon Trout River}

A continuous-record streamgage is on the East Branch Salmon Trout River (USGS station 04043244) (fig. 1). The drainage basin at this station constitutes an area of $10.2 \mathrm{mi}^{2}$. This streamgage is in a channel throughout the reach that is low gradient immediately upstream, with several riffles downstream, and is composed primarily of silt, sand, and gravel. White pines and other large trees are prevalent in the riparian zone and tag alders line the streambanks. The streamgage was made operational October 1, 2005. A water-quality sonde that measures water temperature and specific conductance was installed at this station on December 6, 2005. The streamgage and sonde have run continuously through this study. Conditions for measuring higher streamflows is difficult, or impossible, at the station because of issues with accessing the station during high-flow events. A logging/snowmobile trail bridge constructed in 2014 is about 1,000 ft downstream from the streamgage (Chauncey Moran, Yellow Dog Watershed Preserve, oral commun., 2018). During this study, runoff exceeded the mean-annual runoff for the period of record (25.6 inches) every year, ranging from 25.8 inches in 2014 to 28.6 inches in 2015. Peak streamflow for the period of record at the station, which was on May 11, 2006, is $464 \mathrm{ft}^{3} / \mathrm{s}$. The peak streamflow should be used with some caution as it was interpolated from the stage-discharge rating curve extended above the highest measurement made at the station, which was $121 \mathrm{ft}^{3} / \mathrm{s}$. Lowest streamflow for the period of record was $9.5 \mathrm{ft}^{3} / \mathrm{s}$ and occurred on September 11, 2011, and March 28, 2015.

\section{Methods of Data Collection and Analysis}

Streamflow and water-quality data were collected following USGS protocols. Streamflow measurements were collected using methods described in Rantz and others (1982) and Turnipseed and Sauer (2010). Water-quality and bed-sediment samples were collected following guidelines described in the USGS National Field Manual (U.S. Geological Survey, variously dated). Water and sediment samples were analyzed for chemical concentrations at the USGS National Water Quality Laboratory (NWQL) in Denver, Colorado, which follows a quality-control plan outlined in Maloney (2005). An exception was the analysis of total suspended solids concentrations, which were analyzed at the Indiana Kentucky Water Science Center Sediment Laboratory, which follows a quality-control plan for sample analysis outlined in Shreve and Downs (2005).

\section{Flow Measurement}

During this study, streamflow either was measured concurrent with water-quality sampling at the stream stations using a current meter (acoustic Doppler velocimeter [ADV] or ADCP) or a mechanical meter (Price pygmy or AA), or streamflow was calculated using a stage-discharge rating. Streamflow has been monitored on a real-time basis at the USGS stations Yellow Dog River near Big Bay, Michigan (04043275) and Salmon Trout River near Big Bay, Michigan (04043238) since December 2004 and East Branch Salmon 
Trout River near Dodge City, Michigan (04043244) since December 2005. Historic and current stage and streamflow data from the continuous-record streamgages are available through the USGS National Water Information System (NWIS) online at https://waterdata.usgs.gov $/ \mathrm{mi} / \mathrm{nwis} / \mathrm{sw}$ (U.S. Geological Survey, 2018).

\section{Water-Quality Sample Collection}

Samples were collected during open-water periods only for this study; thus, sampling was not attempted until streams were free of ice and locations were accessible following snow melt. Open-water periods typically meant that sampling would not start until May and would end in early November. Therefore, early winter snowfalls meant that considerable snow may have fallen before the completion of late fall sampling. From 2013 to 2016, fours samples were collected each year at each station with the exception of USGS station 464459087504201, which was sampled only three times in 2014. This station was buried by snow in November 2014 and was not accessible again until May 2015.

\section{Stream Sampling}

Prior to sampling, field water-quality parameters of temperature, dissolved oxygen, $\mathrm{pH}$, and specific conductance were measured, in-stream, using a calibrated multiparameter water-quality sonde. Water samples were then collected using the DH-81 sampler with a 1-liter polypropylene bottle. Samples were collected following either the multiple-vertical or equal-width-increment sampling approach, contingent on if stream velocity allowed for isokinetic sampling (U.S. Geological Survey, variously dated). All samples were composited in a polypropylene churn and either decanted directly into sample bottles for analysis or filtered through a 0.45 -micron capsule filter into bottles for analysis. If required, samples were preserved with acid, stored on ice, and shipped either to the USGS NWQL or the Indiana Kentucky Water Science Center Sediment Laboratory for analysis.

\section{Spring Sampling}

The small springs sampled in the headwaters of the Salmon Trout watershed required adaptation of a point sampling device. Generally, the springs sampled were less than $1 \mathrm{ft}$ wide and 2 to 3 inches deep. A peristaltic pump with $\mathrm{C}-$ Flex tubing was used to convey the spring water to a sample chamber to restrict sample contact with the atmosphere. An inline 0.45 -micron capsule filter was attached to the sample line for collection of the filtered constituents and then was removed for the collection of the whole water constituents (fig. 4). A set of narrow polyvinyl chloride (PVC) pipes was used to secure the peristaltic sample line in the direction of flow from the springs. The larger PVC pipe was 1-inch diameter, the inner PVC pipe was 3/4-inch diameter. The end of the 1-inch diameter pipe was cut on an angle to create a sharpened point to facilitate placement of the pipe into the bed of the spring. At about 5- to 6-inch intervals, $1 / 2$-inch holes were drilled into the side of the outer PVC pipe; only one, 1/2-inch hole was drilled into the inner PVC pipe (fig. 4). Sample tubing was threaded through the aligned holes on the outer and inner PVC pipes and then the inner PVC pipe was lifted to hold the sample tubing in place, taking care not to restrict the flow of water through the sampling tube. The pipe was then pushed into the bed of the spring and adjusted so that the sampling tube was aligned in the direction of flow of the spring and positioned so the tube was totally submerged but not in contact with the bed of the spring. Field parameters were allowed to equilibrate prior to sampling, and any bed material that may have been disturbed by the placement of the device allowed to settle out. After this brief period, the sampling commenced following the standard protocols outlined in the USGS National Field Manual (U.S. Geological Survey, variously dated). If required, samples were preserved with acid, then stored on ice, and shipped to the USGS NWQL for analysis.

\section{Bed-Sediment Collection}

Bed sediments were sampled at all seven surface-water stations in conjunction with water-quality sampling in September 2013 and October 2016. Bed-sediment samples were collected and processed using methods described in the U.S. Geological Survey, National Field Manual, Chapter A8 (U.S. Geological Survey, variously dated) (available online at https://water.usgs.gov/owq/FieldManual/Chapter8/index.html). The samples were analyzed for 13 metals and moisture content at the USGS NWQL.

Bed-sediment samples were composites of samples collected by hand with a polypropylene scoop from each of 5-10 depositional zones (submerged during low streamflow so that all samples were saturated) along a reach of approximately $30 \mathrm{ft}$. The water-quality sampling location was coincident within the sampled reach. Samples were collected from the upper 1-inch layer (most recent, oxidized layer), and the amount collected depended upon the size of the depositional zone. Deposits of fine-grained sediments were targeted for sampling; thus, concentrations represent conditions in depositional areas in streams, not the average concentration of sediments throughout the stream reach. The samples were wet sieved in the field, and the fine (less than $0.08 \mathrm{inch}$ ) fraction 


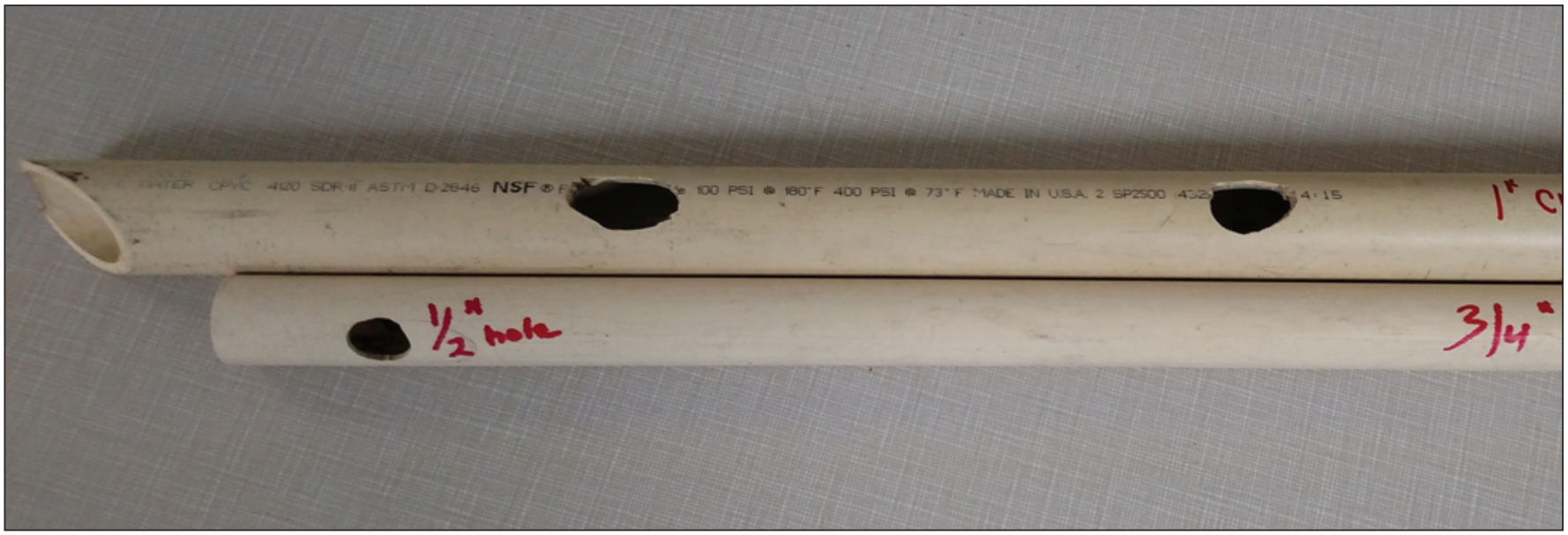

\section{B. Sample collection at U.S. Geological Survey station 464545087522801}

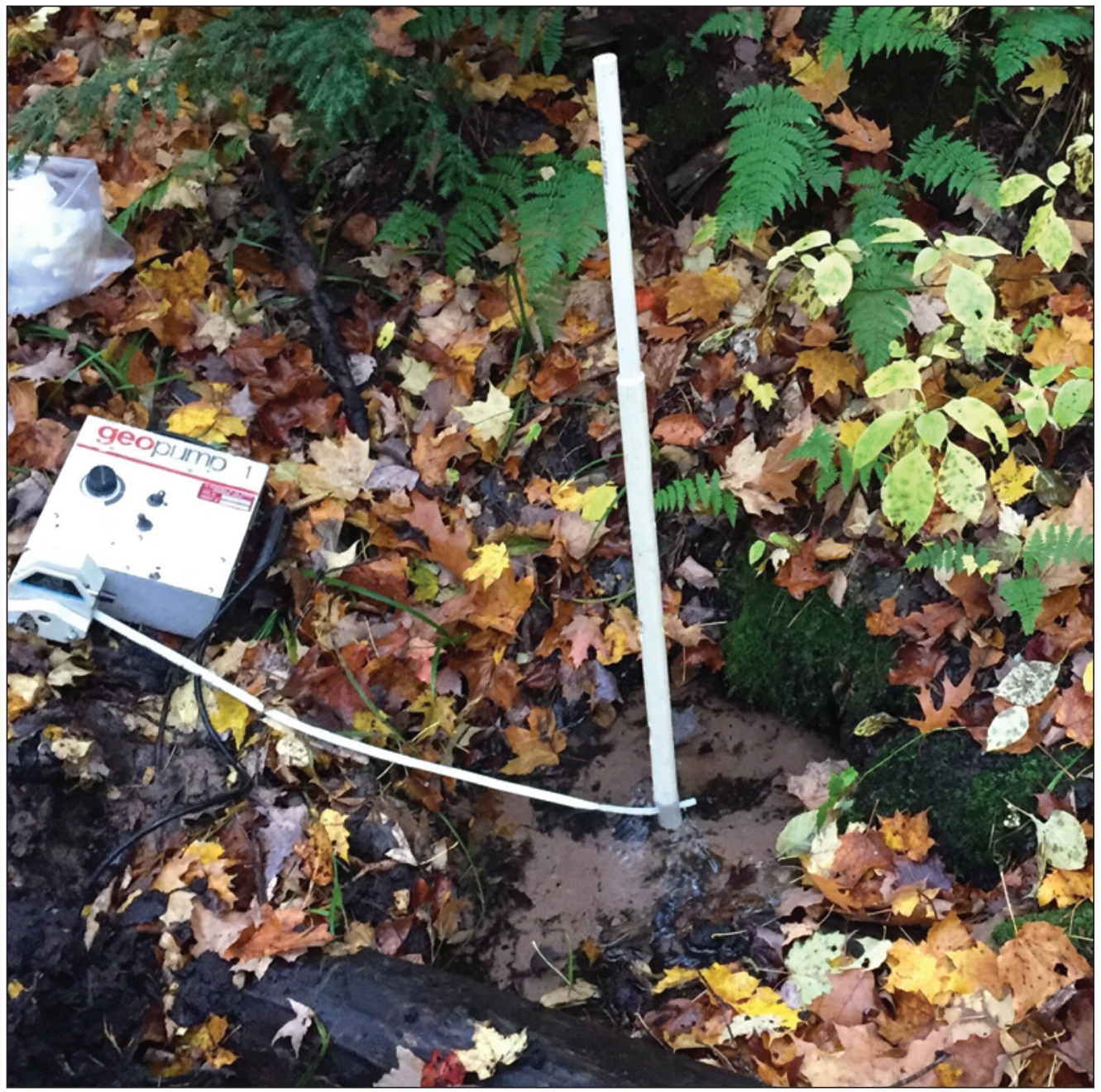

Figure 4. $A$, spring sampling apparatus and $B$, example of spring sample collection at U.S. Geological Survey station 464545087522801 . 
Table 3. Range of reporting levels used by the U.S. Geological Survey National Water Quality Laboratory for constituents sampled during 2013-16.

[mg/L, milligrams per liter; $\mathrm{CaCO}_{3}$, calcium carbonate; $\mu \mathrm{g} / \mathrm{L}$, micrograms per liter; $\mathrm{N}$, nitrogen; $\mathrm{P}$, phosphorus; mg/kg, milligram per kilogram]

\begin{tabular}{|c|c|c|c|}
\hline Constituent name & Units & $\begin{array}{l}\text { Minimum } \\
\text { reporting level }\end{array}$ & $\begin{array}{c}\text { Maximum } \\
\text { reporting level }\end{array}$ \\
\hline \multicolumn{4}{|c|}{ Water-quality constituents } \\
\hline Alkalinity & $\mathrm{mg} / \mathrm{L} \mathrm{CaCO}_{3}$ & 4.0 & 4.6 \\
\hline Aluminum & $\mu \mathrm{g} / \mathrm{L}$ & 2.2 & 3.0 \\
\hline Ammonia & $\mathrm{mg} / \mathrm{L}$ as $\mathrm{N}$ & 0.01 & 0.01 \\
\hline Antimony & $\mu \mathrm{g} / \mathrm{L}$ & 0.027 & 0.03 \\
\hline Arsenic & $\mu \mathrm{g} / \mathrm{L}$ & 0.04 & 0.1 \\
\hline Barium & $\mu \mathrm{g} / \mathrm{L}$ & 0.1 & 0.25 \\
\hline Beryllium & $\mu \mathrm{g} / \mathrm{L}$ & 0.006 & 0.02 \\
\hline Cadmium & $\mu \mathrm{g} / \mathrm{L}$ & 0.016 & 0.03 \\
\hline Calcium & $\mathrm{mg} / \mathrm{L}$ & 0.022 & 0.022 \\
\hline Chloride & $\mathrm{mg} / \mathrm{L}$ & 0.02 & 0.06 \\
\hline Chromium & $\mu \mathrm{g} / \mathrm{L}$ & 0.07 & 0.5 \\
\hline Cobalt & $\mu \mathrm{g} / \mathrm{L}$ & 0.023 & 0.05 \\
\hline Copper & $\mu \mathrm{g} / \mathrm{L}$ & 0.2 & 0.8 \\
\hline Total dissolved solids & $\mathrm{mg} / \mathrm{L}$ & 20.0 & 20.0 \\
\hline Fluoride & $\mathrm{mg} / \mathrm{L}$ & 0.01 & 0.01 \\
\hline Iron & $\mu \mathrm{g} / \mathrm{L}$ & 4.0 & 5.0 \\
\hline Lead & $\mu \mathrm{g} / \mathrm{L}$ & 0.02 & 0.04 \\
\hline Magnesium & $\mathrm{mg} / \mathrm{L}$ & 0.011 & 0.011 \\
\hline Manganese & $\mu \mathrm{g} / \mathrm{L}$ & 0.15 & 0.4 \\
\hline Mercury & $\mu \mathrm{g} / \mathrm{L}$ & 0.005 & 0.005 \\
\hline Molybdenum & $\mu \mathrm{g} / \mathrm{L}$ & 0.014 & 0.05 \\
\hline Nickel & $\mu \mathrm{g} / \mathrm{L}$ & 0.09 & 0.2 \\
\hline Nitrate plus nitrite & $\mathrm{mg} / \mathrm{L}$ as $\mathrm{N}$ & 0.01 & 0.01 \\
\hline Nitrite & $\mathrm{mg} / \mathrm{L}$ as $\mathrm{N}$ & 0.001 & 0.001 \\
\hline Organic carbon & $\mathrm{mg} / \mathrm{L}$ & 0.23 & 0.23 \\
\hline Orthophosphate & $\mathrm{mg} / \mathrm{L}$ as $\mathrm{P}$ & 0.004 & 0.004 \\
\hline Phosphorus filtered & $\mathrm{mg} / \mathrm{L}$ as $\mathrm{P}$ & 0.003 & 0.003 \\
\hline Phosphorus unfiltered & $\mathrm{mg} / \mathrm{L}$ as $\mathrm{P}$ & 0.004 & 0.004 \\
\hline Potassium & $\mathrm{mg} / \mathrm{L}$ & 0.03 & 0.06 \\
\hline Selenium & $\mu \mathrm{g} / \mathrm{L}$ & 0.03 & 0.05 \\
\hline Silica & $\mathrm{mg} / \mathrm{L}$ & 0.018 & 0.018 \\
\hline Silver & $\mu \mathrm{g} / \mathrm{L}$ & 0.005 & 1.0 \\
\hline Sodium & $\mathrm{mg} / \mathrm{L}$ & 0.06 & 0.1 \\
\hline Sulfate & $\mathrm{mg} / \mathrm{L}$ & 0.02 & 0.09 \\
\hline Suspended sediment concentration (SSC) & $\mathrm{mg} / \mathrm{L}$ & 1.0 & 1.0 \\
\hline Nitrogen filtered & $\mathrm{mg} / \mathrm{L}$ & 0.05 & 0.05 \\
\hline Nitrogen unfiltered & $\mathrm{mg} / \mathrm{L}$ & 0.05 & 0.05 \\
\hline Uranium & $\mu \mathrm{g} / \mathrm{L}$ & 0.004 & 0.014 \\
\hline Vanadium & $\mu \mathrm{g} / \mathrm{L}$ & 0.1 & 0.1 \\
\hline Zinc & $\mu \mathrm{g} / \mathrm{L}$ & 1.4 & 2.0 \\
\hline
\end{tabular}


Table 3. Range of reporting levels used by the U.S. Geological Survey National Water Quality Laboratory for constituents sampled during 2013-16.-Continued

[mg/L, milligrams per liter; $\mathrm{CaCO}_{3}$, calcium carbonate; $\mu \mathrm{g} / \mathrm{L}$, micrograms per liter; $\mathrm{N}$, nitrogen; $\mathrm{P}$, phosphorus; $\mathrm{mg} / \mathrm{kg}$, milligram per kilogram]

\begin{tabular}{lccc}
\hline Constituent name & Units & $\begin{array}{c}\text { Minimum } \\
\text { reporting level }\end{array}$ & $\begin{array}{c}\text { Maximum } \\
\text { reporting level }\end{array}$ \\
\hline Aluminum & Bed-sediment constituents & 25.0 & 0.1 \\
Arsenic & $\mathrm{mg} / \mathrm{kg}$ & 0.1 & 0.1 \\
Chromium & $\mathrm{mg} / \mathrm{kg}$ & 0.1 & 0.1 \\
Cobalt & $\mathrm{mg} / \mathrm{kg}$ & 0.1 & 0.1 \\
Copper & $\mathrm{mg} / \mathrm{kg}$ & 0.1 & 4.6 \\
Iron & $\mathrm{mg} / \mathrm{kg}$ & 4.6 & 0.1 \\
Lead & $\mathrm{mg} / \mathrm{kg}$ & 0.1 & 0.2 \\
Manganese & $\mathrm{mg} / \mathrm{kg}$ & 0.2 & 0.005 \\
Mercury & $\mathrm{mg} / \mathrm{kg}$ & 0.005 & 0.1 \\
Molybdenum & $\mathrm{mg} / \mathrm{kg}$ & 0.1 & 0.1 \\
Nickel & $\mathrm{mg} / \mathrm{kg}$ & 0.1 & 0.1 \\
Selenium & $\mathrm{mg} / \mathrm{kg}$ & 0.1 & 2.0 \\
Zinc & $\mathrm{mg} / \mathrm{kg}$ & 2.0 & \\
\hline
\end{tabular}

was collected for trace-metal analysis. Samples were then placed in sample jars, stored on ice, and shipped to the USGS NWQL for analysis.

\section{Water-Quality Analysis and Results}

Water-quality samples were analyzed for a suite of constituents that includes major ions, nutrients, and trace metals. Bed-sediment samples were analyzed for trace-metal constituents. A list of the measured constituents and their respective reporting levels are provided in table 3. Reporting levels for some constituents varied during the study, so a reporting level is provided as a range for the period of study in table 3 . This range of reporting levels does not include temporary instances where reporting levels may have been raised, such as for a diluted sample. A detailed description of the types of reporting levels used and how they are developed by the NWQL are in Childress and others (1999) and Williams and others (2015). In general, the reporting level represents a concentration determined below which a value cannot be reliably reported as a numerical value. When analysis of a sample determined a constituent concentration to be less than the reporting level, then the constituent concentration value was considered censored.

\section{Quality-Assurance Samples}

For the purposes of quality assurance, replicate and blank samples were collected for the water-quality samples. In addition, replicate samples were also collected for bedsediment samples. Split replicate water samples were collected for stream samples, and a sequential replicate was collected at spring stations. Split replicates are samples collected by dividing one sample into two subsamples and analyzing those subsamples for the same constituents. Sequential replicates are samples collected consecutively, one after the other, and analyzed for identical constituents. Both types of replicates are useful in determining the variability in constituent concentrations because of field and laboratory processes (U.S. Geological Survey, variously dated). Sequential replicates also incorporate naturally occurring heterogeneity in the water sampled because the samples are not collected concurrently. The number of replicate samples collected ranged from 9 to 43 and was dependent on the constituent (table 4). To compare samples, the relative percent difference between the environmental sample and replicate sample value was calculated (table 4). If a constituent concentration was censored, then a value of one-half of the censored value was substituted for the censored value for the purposes of comparison.

Upon comparison, a low relative percent difference in concentration between the environmental and associated replicate sample was observed for most of constituents (table 4). Median values of relative percent differences are low, indicating good precision in analysis and generally low natural variability in the stream or spring sampling location. Constituents with high median relative percent differences, such as cobalt concentration, indicate lower precision and higher variability because of processing. In the case of cobalt, the high-capacity filters used for sample processing were determined to be a potential source of contamination for cobalt in the samples collected for this study (U.S. Geological Survey, 2016); therefore, some of the variability in the cobalt concentrations potentially is a result of contamination from the filter. Consequently, cobalt results were given either a remark code of "V", 
Table 4. Comparison of replicate samples collected for water-quality constituents.

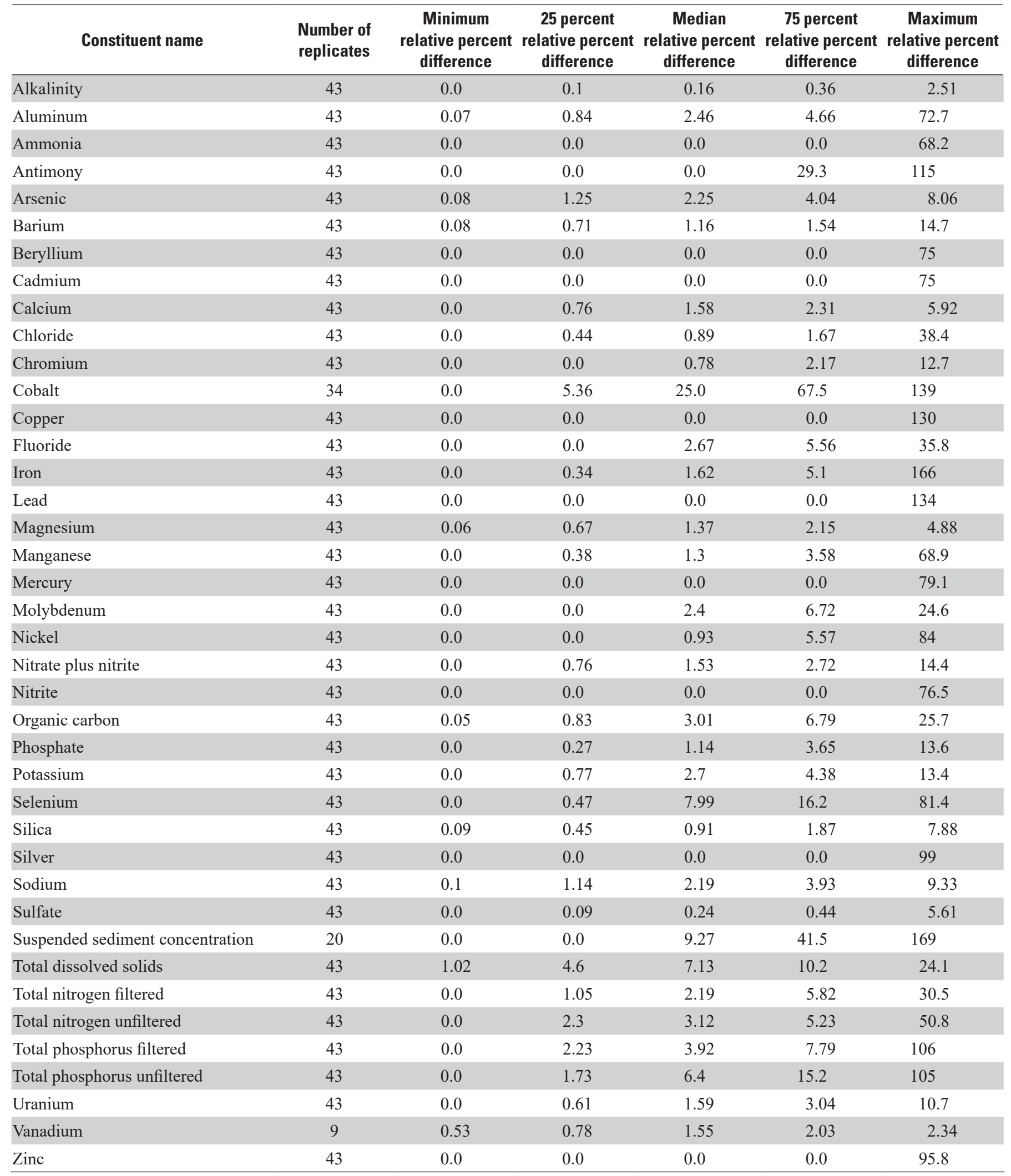


indicating concentrations potentially affected by contamination, or a remark code of " $<$ ", indicating concentrations below the reporting level. The maximum relative percent difference can be quite high for some of these constituents (table 4); however, many of these values are for constituents with typically very low concentrations (antimony, copper, and lead). As a result, any deviation between the environmental and replicate sample will manifest in a large relative percent difference.

Split replicate samples were collected for the bed-sediment samples analyzed for metals. A total of 4 replicates were collected in conjunction with the 14 bed-sediment samples. The results of the comparison of the replicates to the environmental samples are listed in table 5 . The variability associated with these samples is much higher than with the associated water samples, which implies that the sediment is likely a more heterogeneous medium. However, the total number of replicates analyzed is low compared to the number of replicate water samples analyzed.

A total of 28 field blank samples were collected during the study. Field blanks were used to assess potential contamination of samples with relation to specific constituents that may have been introduced from the sample collection and processing for this study. A summary of the field blank results is listed in table 6. In general, the results indicate few issues with contamination because of sampling procedures. However, multiple occurrences of low-level concentrations of ammonia and cobalt were detected in field blank samples. Issues with cobalt being detected in blanks are related to contamination associated with the manufacturing of the capsule filters used for sampling (U.S. Geological Survey, 2016). Ammonia was also measured in 7 of 28 samples, but at concentrations close to the reporting level of 0.01 milligram per liter $(\mathrm{mg} / \mathrm{L})$. Previous studies have determined that ammonia samples are susceptible to contamination from airborne sources, as well as from shipping and some laboratory procedures (Fishman, 1993; Mueller and Titus, 2005; Medalie and Martin, 2017).

The presence of low levels of ammonia in the blanks indicates that ammonia concentrations in environmental samples have more uncertainty associated with those results.

\section{Water Sample Analysis}

A total of 239 water-quality samples were collected at 15 stations, 7 streams and 8 springs, during the study period from May 2013 to October 2016. Samples were typically collected from May to November during the study; however, one sample from a spring (USGS station 464459087504201) was not collected in November 2014 because the station was buried under snow and inaccessible. Water-quality results for those samples collected during this study are stored in the USGS NWIS database and can be accessed at https://goo.gl/KwKkD8. Where applicable, collected constituent concentrations are compared to aquatic-health guidelines for surface water in Michigan. State of Michigan aquatic-health criteria for surface waters are described in Rule 57 (Michigan Department of Environmental Quality, 2018). Two criteria used in the report for comparison are the final chronic value (FCV) and aquatic maximum value (AMV). The FCV is defined as the concentration that does not allow injurious or debilitating effects in an aquatic organism resulting from repeated long-term exposure to a substance relative to the organism's lifespan (Michigan Department

Table 5. Comparison of replicate samples collected for bed-sediment constituents.

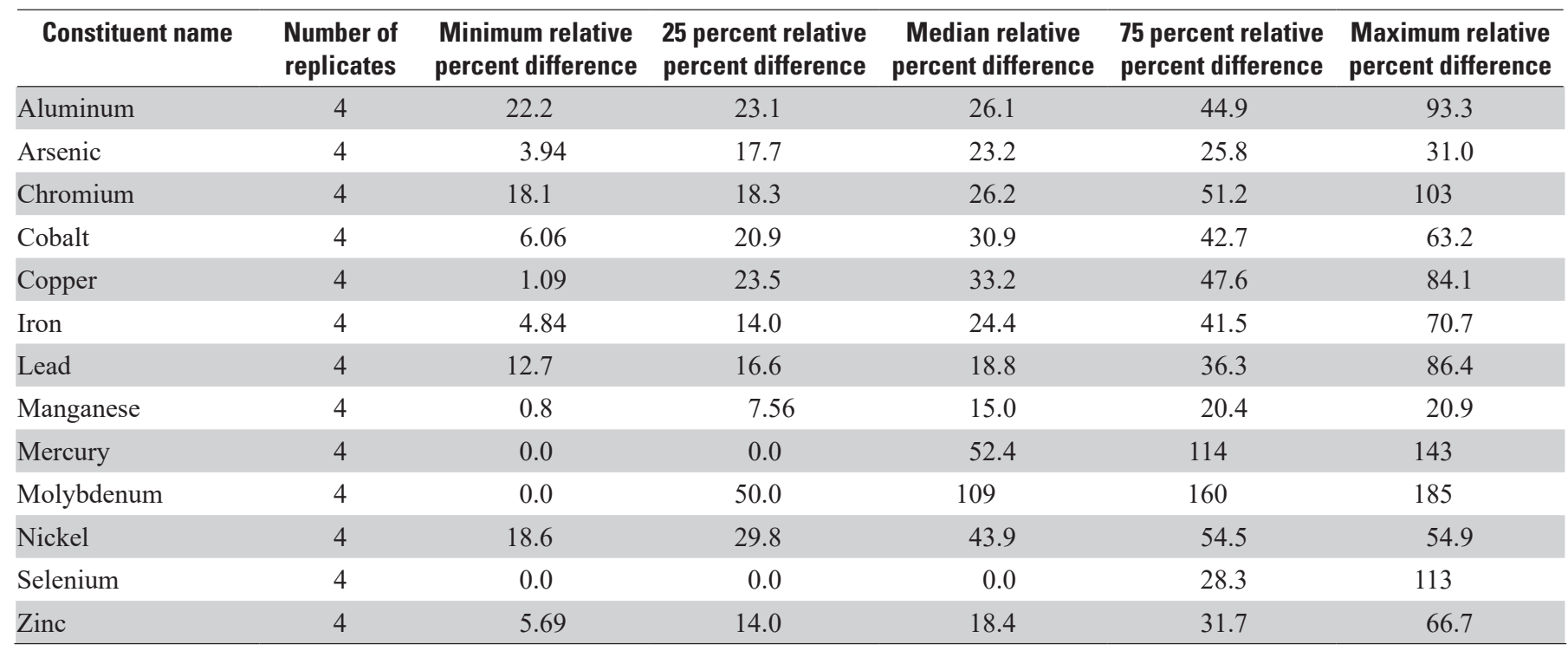


Table 6. Summary of field blank data collected for waterquality constituents.

\begin{tabular}{|c|c|c|c|}
\hline Constituent name & $\begin{array}{l}\text { Number of } \\
\text { censored } \\
\text { results }\end{array}$ & $\begin{array}{l}\text { Number of } \\
\text { results with } \\
\text { quantified } \\
\text { concentration }\end{array}$ & $\begin{array}{c}\text { Number } \\
\text { of blanks } \\
\text { samples } \\
\text { collected }\end{array}$ \\
\hline Aluminum & 28 & 0 & 28 \\
\hline Ammonia & 21 & 7 & 28 \\
\hline Antimony & 26 & 2 & 28 \\
\hline Arsenic & 28 & 0 & 28 \\
\hline Barium & 27 & 1 & 28 \\
\hline Beryllium & 28 & 0 & 28 \\
\hline Cadmium & 28 & 0 & 28 \\
\hline Calcium & 28 & 0 & 28 \\
\hline Chloride & 26 & 2 & 28 \\
\hline Chromium & 28 & 0 & 28 \\
\hline Cobalt & 14 & 6 & 20 \\
\hline Copper & 28 & 0 & 28 \\
\hline Fluoride & 27 & 1 & 28 \\
\hline Nitrate plus nitrite & 28 & 0 & 28 \\
\hline Iron & 28 & 0 & 28 \\
\hline Lead & 28 & 0 & 28 \\
\hline Magnesium & 28 & 0 & 28 \\
\hline Manganese & 28 & 0 & 28 \\
\hline Mercury & 28 & 0 & 28 \\
\hline Molybdenum & 28 & 0 & 28 \\
\hline Nickel & 28 & 0 & 28 \\
\hline Nitrite & 27 & 1 & 28 \\
\hline Organic carbon & 24 & 4 & 28 \\
\hline Phosphate & 28 & 0 & 28 \\
\hline Potassium & 28 & 0 & 28 \\
\hline Selenium & 28 & 0 & 28 \\
\hline Silica & 26 & 2 & 28 \\
\hline Silver & 28 & 0 & 28 \\
\hline Sodium & 28 & 0 & 28 \\
\hline Sulfate & 27 & 1 & 28 \\
\hline $\begin{array}{l}\text { Suspended sediment } \\
\text { concentration }\end{array}$ & 5 & 4 & 9 \\
\hline Total dissolved solids & 27 & 1 & 28 \\
\hline Total nitrogen filtered & 28 & 0 & 28 \\
\hline Total nitrogen unfiltered & 25 & 3 & 28 \\
\hline Total phosphorus filtered & 28 & 0 & 28 \\
\hline $\begin{array}{l}\text { Total phosphorus } \\
\text { unfiltered }\end{array}$ & 26 & 2 & 28 \\
\hline Uranium & 28 & 0 & 28 \\
\hline Vanadium & 8 & 0 & 8 \\
\hline Zinc & 27 & 1 & 28 \\
\hline
\end{tabular}



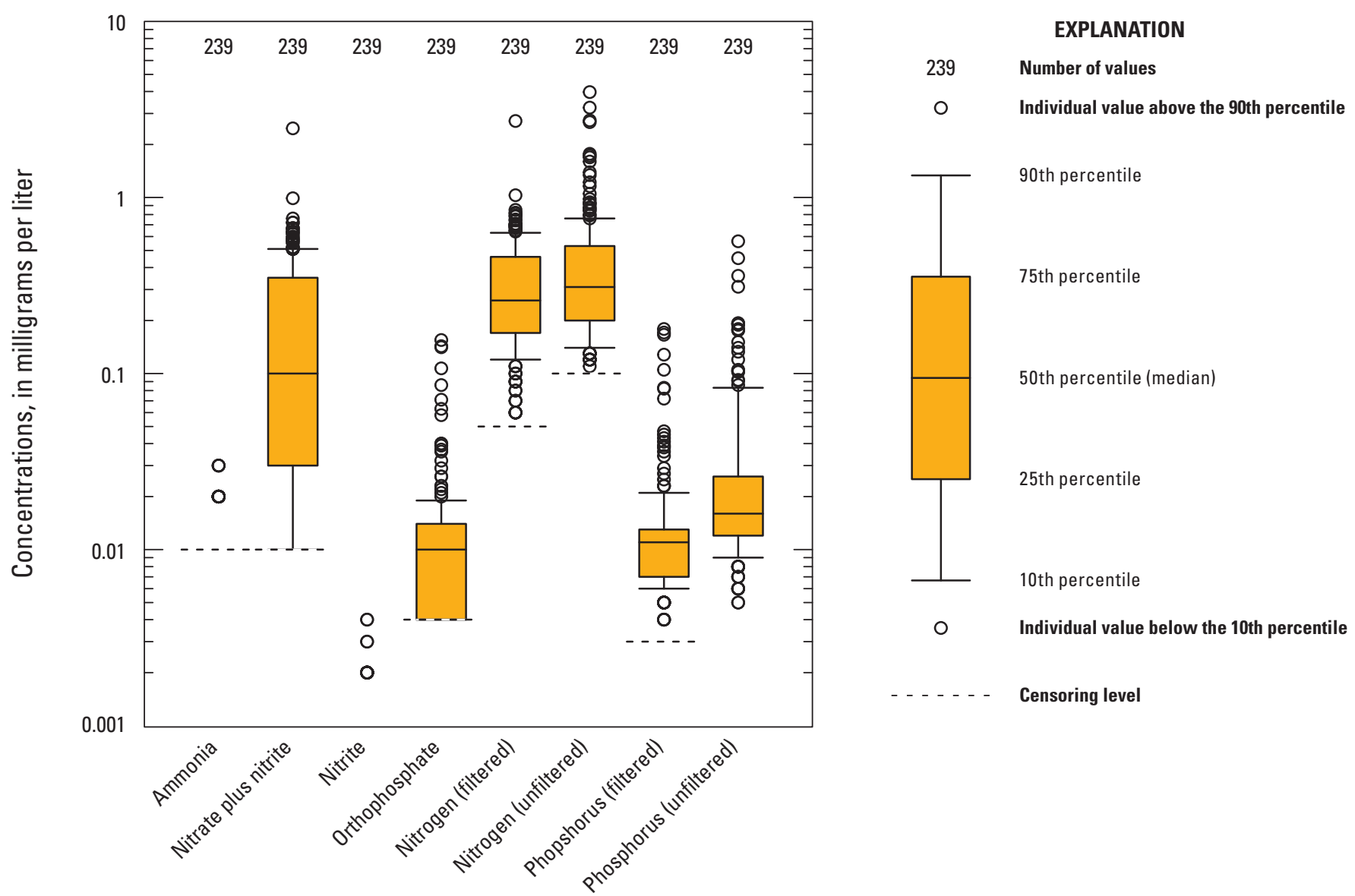

Figure 5. Distribution of nutrient concentrations sampled in streams and springs in the Yellow Dog and Salmon Trout watersheds, 2013-16.

also analyzed from filtered and unfiltered samples. Similar to the other nutrients, total phosphorus values were quite low ranging from less than 0.003 to $0.179 \mathrm{mg} / \mathrm{L}$ in filtered samples and from 0.005 to $0.56 \mathrm{mg} / \mathrm{L}$ (fig. 5) in unfiltered samples. The low values of nutrients in the water collected in the watershed do not seem to indicate any measurable influence from sewer, septic, or fertilizer sources.

\section{Copper and Nickel}

Copper and nickel are the principal target metals from the Eagle Mine (Eagle Mine, 2017). Delineating the background concentrations of copper and nickel in the environment is critical for monitoring any potential changes to these constituents as a result of changes in the watershed. Copper concentrations in the streams and springs ranged from below the minimum reporting level of $0.2 \mu \mathrm{g} / \mathrm{L}$ ( 80 percent of all samples) to a maximum of $3.2 \mu \mathrm{g} / \mathrm{L}$ (fig. 6). No trends were apparent in copper concentrations at any of the stations analyzed. The FCV and AMV for copper, as well as many other metal constituents, are based on water hardness, so the criteria vary with water hardness. The FCV threshold for copper was exceeded once for USGS station 04043237 and four times for USGS station 464543087523001 . The AMV was exceeded once for the spring at USGS station 464543087523001 . Special sitespecific criteria have been created for copper in several places in Michigan's Upper Peninsula given the ubiquity of copper in the region (Michigan Department of Environmental Quality, 2018). Researchers have determined that basing aquatic health criteria on water hardness alone may be overprotective, and other measures that account for reduced toxicity because of metal complexing to suspended material and organic ligands may need to be incorporated in the development of criteria (Great Lakes Environmental Center, 2006).

Nickel concentrations ranged from less than 0.09 to $1.4 \mu \mathrm{g} / \mathrm{L}$ (fig. 6). Approximately 48 percent of the samples collected were censored below the reporting level. No trends were apparent in nickel concentrations at any of the stations. None of the samples analyzed for nickel exceeded the FCV or AMV aquatic health criteria. 

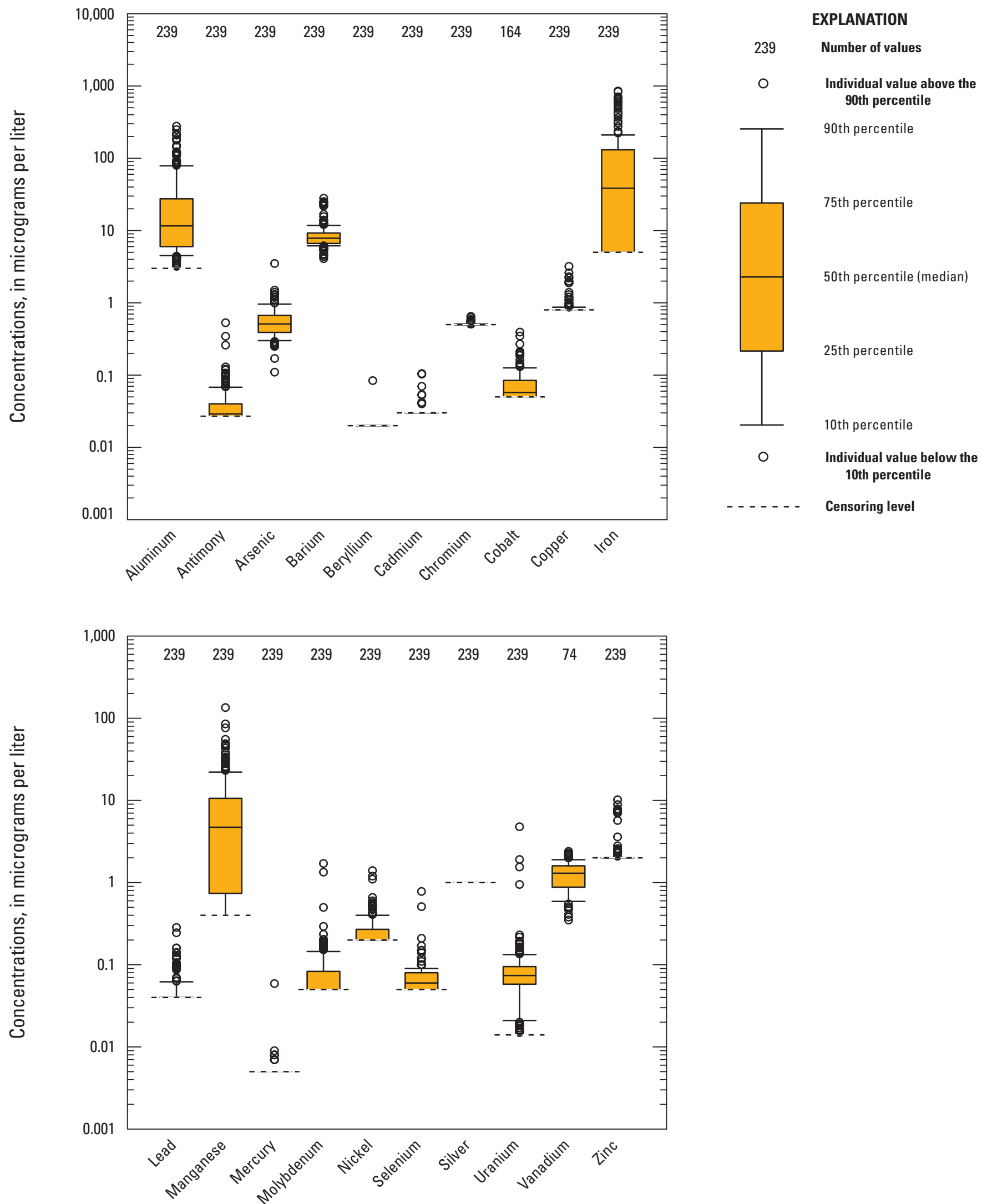

Figure 6. Distribution of selected metal concentrations sampled in streams and springs in the Yellow Dog and Salmon Trout watersheds, 2013-16. 


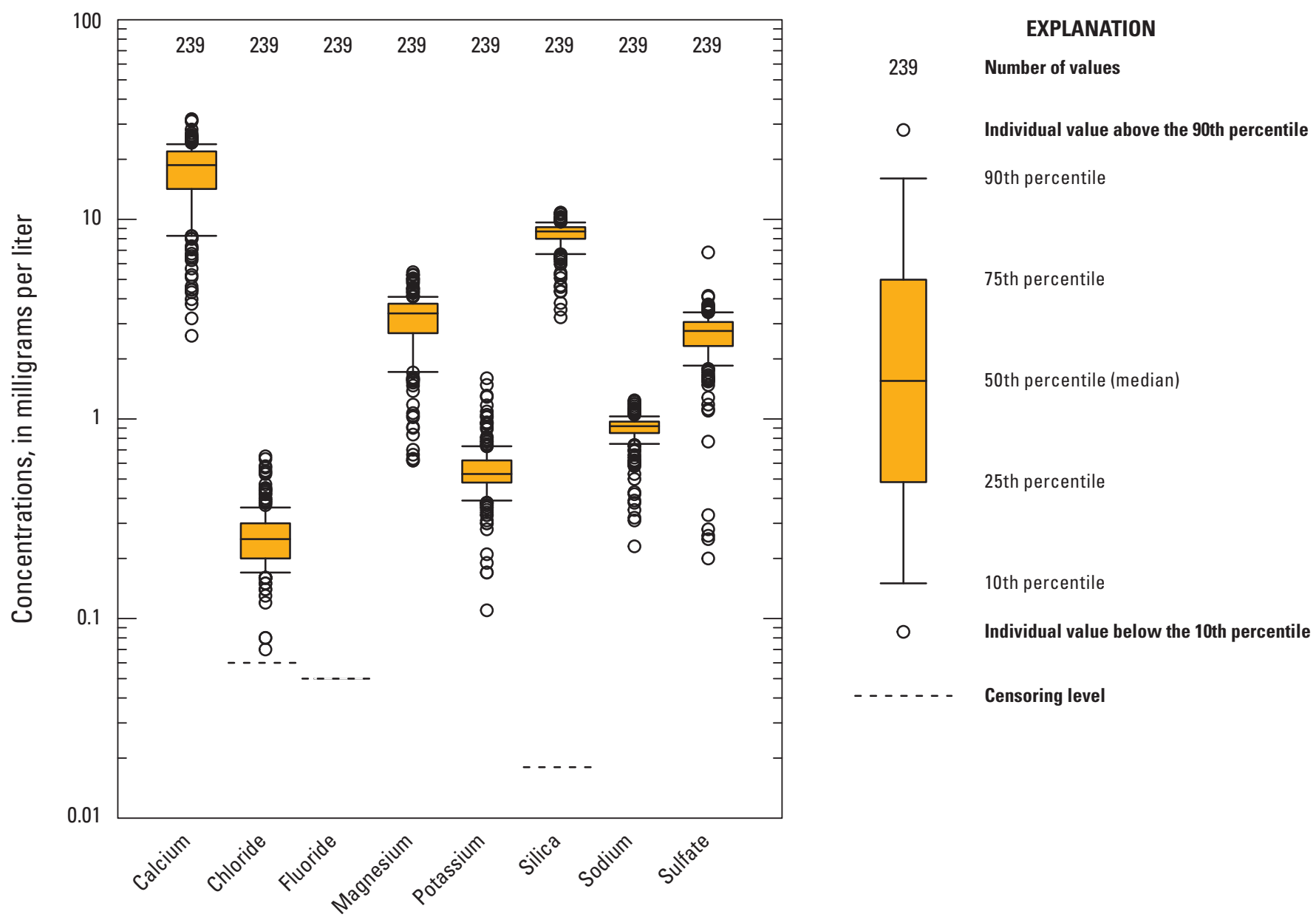

Figure 7. Distribution of selected major ion concentrations sampled in streams and springs in the Yellow Dog and Salmon Trout watersheds, 2013-16.

\section{Mercury}

Mercury contamination has been detected in game fish within Marquette County (Weaver and others, 2010). Potential sources of mercury in the watershed include bedrock sources (including Michigamme Slate) but the most likely source is atmospheric deposition (Weaver and others, 2010). Mercury samples collected for this study were filtered. Speciation of mercury was not investigated as part of this analysis. Mercury concentrations were low; approximately 96 percent of the total samples were censored. None of the nine samples that had a value reported above the reporting level of $0.005 \mu \mathrm{g} / \mathrm{L}$ neared the FCV $(0.77 \mu \mathrm{g} / \mathrm{L})$ or AMV $(1.4 \mu \mathrm{g} / \mathrm{L})$ aquatic health criteria. The maximum mercury concentration was $0.059 \mu \mathrm{g} / \mathrm{L}$ (fig. 6), detected in a sample collected from USGS station 464543087523001 in August 2013. No trends were apparent in mercury concentrations during the sampling period.

\section{Results of Select Constituents}

Of the remaining constituents that had an associated FCV and AMV, only silver exceeded the aquatic health criteria and only in two instances. In one instance, the sample collected at USGS station 464541087523301 on May 7, 2015, exceeded both the AMV and FCV with a value of $0.66 \mu \mathrm{g} / \mathrm{L}$. In the other instance, the sample collected at USGS station 464539087532301 on September 22, 2015, exceeded the FCV with a value of $0.063 \mu \mathrm{g} / \mathrm{L}$. In general, silver concentrations were quite low throughout the watersheds, with 97 percent of the results below the reporting level. The reporting level was raised to $1.0 \mu \mathrm{g} / \mathrm{L}$ for the last two samples collected (fig. 6). This reporting level is above the FCV and AMV for silver.

Chloride is a constituent often associated with anthropogenic activity because chloride is detected in waste effluent and is used for deicing of roads during winter. Chloride concentrations measured in samples from the springs and streams of the watersheds are low with a range of concentrations from 0.03 to $0.65 \mathrm{mg} / \mathrm{L}$ (fig. 7). For perspective, this concentration is in the same range as the chloride concentration detected in precipitation in this region (Berner and Berner, 1996). 
In general, stream stations had slightly higher concentrations than spring stations, with median concentrations of 0.26 and $0.24 \mathrm{mg} / \mathrm{L}$, respectively. Chloride concentrations did not seem to correlate with streamflow, however, concentrations did correlate seasonally with higher concentrations observed in fall compared to spring and summer. Two streams, USGS stations 04043237 and 04043238, appeared to have an apparent increasing trend in chloride concentration; however, no formal trend test was applied to quantify a trend because of the limited sample size of the concentration values for each station.

\section{Bed-Sediment Analysis}

Bed-sediment samples were collected at all seven stream stations in conjunction with water-quality sampling in September 2013 and again in October 2016, and samples were analyzed for a suite of organic chemicals as well as metals. To put the constituent concentration results of these analyses in context, the bed-sediment samples were compared to sediment-quality guidelines. Sediment-quality guidelines often are built around concerns about specific groups of contaminants such as organochlorine insecticides, industrial organochlorine compounds such as polychlorinated biphenyls, and polycyclic aromatic hydrocarbons. Chemical analyses for this study focused on determining concentrations for a full suite of metals. Unfortunately, sediment-quality guidelines have been developed for only a small group of metals collected from freshwater streams and lakes.

Results of the metals analysis for the study area are presented in the NWIS database (https://goo.gl/KwKkD8). The distribution of concentrations of arsenic, chromium, copper, lead, mercury, nickel, and zinc detected in bed-sediment samples is illustrated in figure 8 . All constituents shown in figure 8 were above the reporting level except for two zinc samples and six mercury samples. The threshold effect concentration (TEC) and probable effect concentration (PEC) thresholds are presented in figure 8 for reference purposes and illustrate that none of the thresholds were exceeded by any of the analytes.

MacDonald and others (2000) developed the following two criteria for bed sediment in freshwater environments: the TEC, which represents the concentration above which adverse effects on biota are expected, and the PEC, which defines the concentration above which adverse effects on biota are expected to occur frequently. These criteria were developed

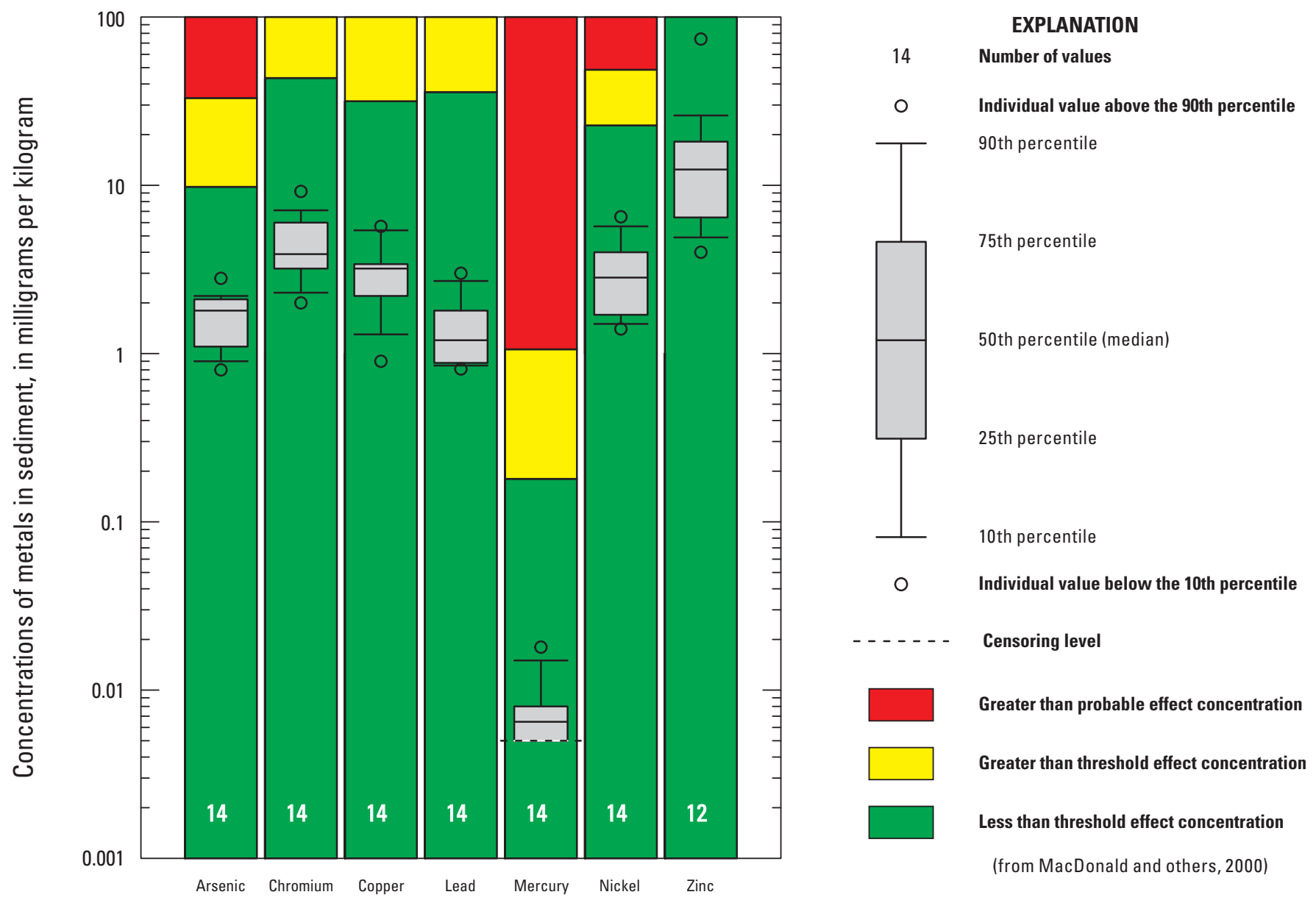

Figure 8. Distribution of bed-sediment concentrations for select metals with associated threshold effect concentration and probable effect concentrations. 
Table 7. Consensus-based sediment-quality guidelines for freshwater ecosystems (MacDonald and others, 2000).

[TEC, threshold effect concentration; $\mu \mathrm{g} / \mathrm{g}$, micrograms per gram; PEC, probable effect concentration]

\begin{tabular}{lcc}
\hline \multicolumn{1}{r}{ Constituent } & TEC $(\boldsymbol{\mu} \mathbf{g} / \mathbf{g})$ & PEC $(\boldsymbol{\mu g} / \mathbf{g})$ \\
\hline Arsenic & 9.79 & 33.0 \\
Cadmium & 0.99 & 4.98 \\
Chromium & 43.4 & 111 \\
Copper & 31.6 & 149 \\
Lead & 35.8 & 128 \\
Mercury & 0.18 & 1.06 \\
Nickel & 22.7 & 48.6 \\
Zinc & 121 & 459
\end{tabular}

through a consensus-based analysis of six other numerical sediment-quality guidelines. Metals for which TECs and PECs have been defined are arsenic, cadmium, chromium, copper, lead, mercury, nickel, and zinc (table 7). With one exception, concentrations of metals from all samples collected for this study were at least an order of magnitude lower than their corresponding TECs (fig. 8). One sample, collected at USGS station 040432383 on September 14, 2013, had an elevated zinc concentration (74 milligrams per kilogram $[\mathrm{mg} / \mathrm{kg}]$ ) but was still below the TEC. The analysis of two other samples for zinc required dilution of the sample to complete the analysis; as a result, the laboratory raised the reporting level to $20 \mathrm{mg} /$ $\mathrm{kg}$. Both of those samples were reported as being below the $20 \mathrm{mg} / \mathrm{kg}$ reporting level. Consequently, including those sample results would have masked nine other zinc sample results in figure 8 and prevented illustrating the distribution of zinc concentrations detected in bed sediment. As a result, those sample concentrations were not used in developing the distribution shown in figure 8 .

In addition to the constituents discussed previously, aluminum, cobalt, iron, manganese, molybdenum, and selenium were also analyzed in the bed sediments that were sampled. These constituents do not have an associated sediment-quality guideline. Distributions of these constituents in the bed sediments of the seven streams that were sampled are shown in figure 9. In general, the median constituent concentrations in bed sediment collected in 2013 were greater than those collected in 2016. The only exceptions were for copper, which median concentrations stayed the same $(3.2 \mathrm{mg} / \mathrm{kg})$, and for manganese, which had slightly increased median concentrations from 2013 to 2016 (61 to $75 \mathrm{mg} / \mathrm{kg}$ ). Lastly, not enough

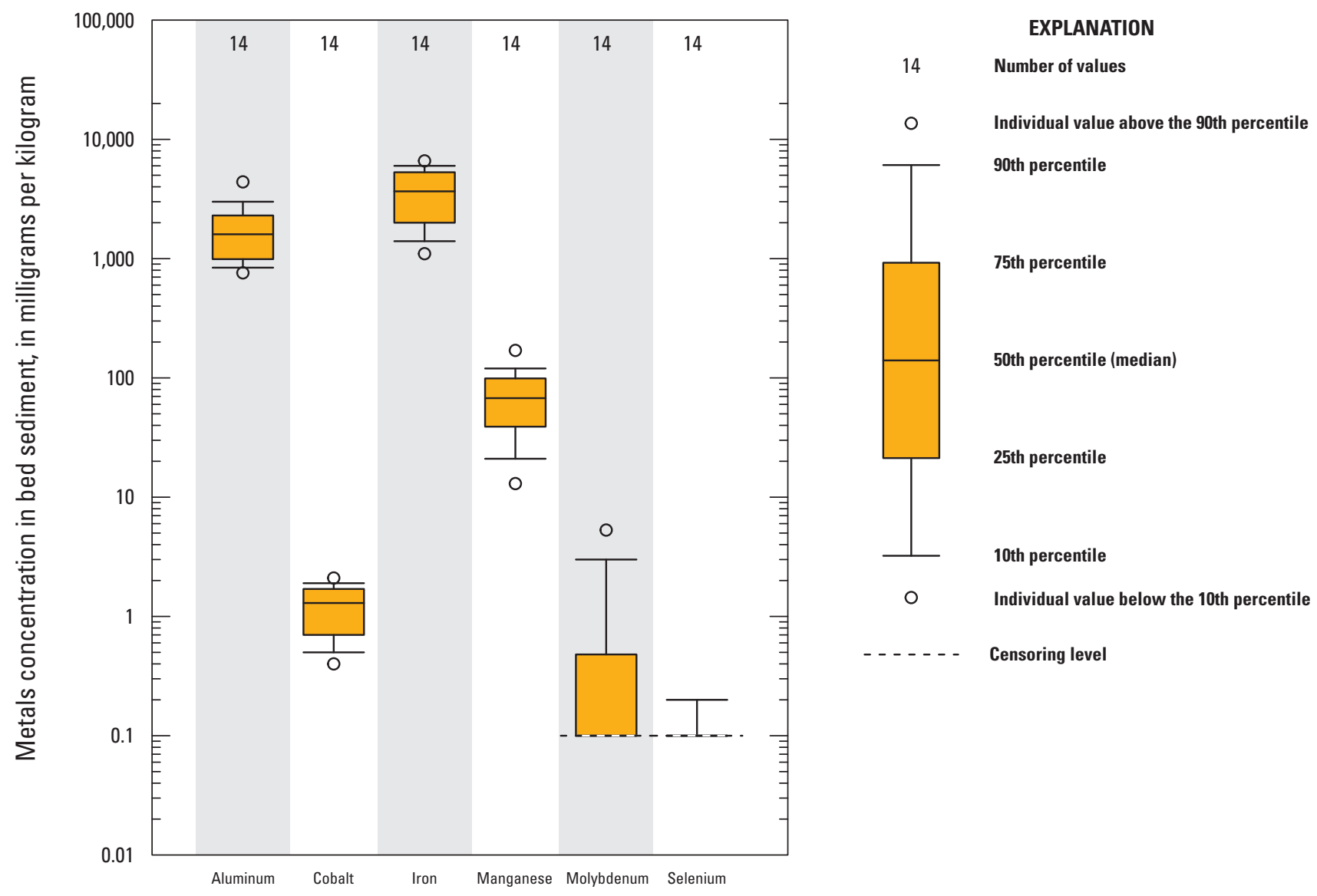

Figure 9. Distribution of select metal concentrations in bed-sediment samples. 
uncensored molybdenum values were available in 2013 to make a valid comparison of median concentrations between the 2013 and 2016 data.

\section{Summary}

In 2013, the USGS, in cooperation with Keweenaw Bay Indian Community, developed a water-quality monitoring program for the Yellow Dog and Salmon Trout watersheds in Marquette County, Michigan. The objectives of the program were to examine the hydrology and to characterize the water quality prior to the development of mineral resources in the Yellow Dog and Salmon Trout watersheds.

Continuous-record streamgaging was used in conjunction with miscellaneous streamflow measurements to investigate the hydrology of the watersheds. Three continuous-record streamgages (USGS stations 04043238, 04043244, and 04043275) were used to identify runoff and baseflow components of streamflow and the relative magnitudes of those components. Specifically, the USGS Groundwater Toolbox was used to estimate the baseflow and runoff components on an annual basis. In general, the streamflow at all three stations was dominated by groundwater discharge with about 70 to 80 percent of the annual streamflow identified as groundwaterderived baseflow. In addition, watershed-scale estimates of precipitation and evapotranspiration on a monthly time-scale were examined to identify the dynamics of components of the water budget. Evapotranspiration is greatest during the summer when it is also greater than precipitation in the watersheds. During the summer, water is likely removed from storage to offset the water deficit. During the fall, winter, and spring, however, precipitation is greater than evapotranspiration and so, water either exits as runoff or goes into storage during that time.

During the period from May 2013 to October 2016, a total of 239 water-quality samples were collected at 15 sampling stations (8 springs, 7 streams) within the Yellow Dog and Salmon Trout watersheds. All samples were analyzed for nutrient, trace-metal, and major-ion species with additional suspended-sediment samples collected at stream stations. Quality-assurance samples collected in conjunction with the sampling program indicated increased uncertainty in the low concentrations associated with ammonia sampled during this study. When applicable, water-quality results were compared to aquatic health guidelines used by the Michigan Department of Environmental Quality. Of the constituents sampled, only copper and silver exceeded aquatic health guidelines. Copper exceeded the final chronic value five times and the aquatic maximum value once, whereas silver exceeded the final chronic value twice and the aquatic maximum value once. Results indicate that chloride concentrations may be increasing at some stations, but concentration values are still quite low.

Bed-sediment chemistry was evaluated twice for each stream sampling station. Samples were collected in the first and last year of the study period and analyzed for trace metals. Where applicable, sediment chemistry results were compared to consensus-based sediment-quality guidelines. None of the metal constituents analyzed exceeded the threshold effect concentration and probable effect concentration thresholds, indicating a healthy aquatic environment in relation to bedsediment quality.

The sediment and water-quality data collected during this study period provide a basis from which to assess perturbations of the environment related to future land use changes and development. The Yellow Dog and Salmon Trout watersheds are critical habitat for sensitive fish species such as the coaster brook trout. Therefore, protecting these watersheds is important in maintaining a diverse and healthy aquatic ecosystem. Future sediment and water-quality data collection in these watersheds can use the techniques from this study to enable equivalent comparisons with the data collected from this study.

\section{References Cited}

Barlow, P.M., Cunningham, W.L., Zhai, Tong, and Gray, Mark, 2014, U.S. Geological Survey groundwater toolbox, a graphical and mapping interface for analysis of hydrologic data (version 1.0) - User guide for estimation of base flow, runoff, and groundwater recharge from streamflow data: U.S. Geological Survey Techniques and Methods, book 3, chap. B10, 27 p., https://dx.doi.org/10.3133/tm3B10.

Berner, E.K., and Berner, R.A., 1996, Global environmentWater, air, and geochemical cycles: Upper Saddle River, N.J., Prentice Hall, p. 376.

Brubaker, L.B, 1975, Postglacial forest patterns associated with till and outwash in north central Upper Michigan: Quaternary Research, v. 5, no. 4, p. 499-527.

Cambray, F.W., 1978, Plate tectonics as a model for the development of deposition and deformation of the early Proterozoic of northern Michigan: Geological Society of America Abstracts with Programs, v. 10, 376 p.

Cannon, W.F., and Simmons, G.C., 1973, Geology of part of the southern complex, Marquette district, Michigan: U.S. Geological Survey Journal of Research, v. 1, no. 2, p. $165-172$.

Childress, C.J.O., Foreman, W.T., Connor, B.F., and Maloney, T.J., 1999, New reporting procedures based on longterm method detection levels and some considerations for interpretations of water-quality data provided by the U.S. Geological Survey National Water Quality Laboratory: U.S. Geological Survey Open-File Report 99-193, 19 p. [Also available at http://water.usgs.gov/owq/OFR_99-193/index. html.] 
Eagle Mine, 2017, Eagle Mine a subsidiary of Lundin Mining web page, accessed May 4, 2017, at http://eaglemine.com/.

Eagle Mine, 2014, 2013 Annual Mining and Reclamation Report Mine Permit MP 01 2007, accessed September 27, 2018, at http://swpcemp.org/wp-content/uploads/2012/10/ Eagle-Mine-2013-Annual-Report.pdf .

Farrand, W.R., and Bell, D.L., 1982, Quaternary geology of Northern Michigan: Ann Arbor, Mich., Department of Geological Sciences, University of Michigan, scale 1:500,000.

Fishman, M.J., ed., 1993, Methods of analysis by the U.S. Geological Survey National Water Quality LaboratoryDetermination of inorganic and organic constituents in water and fluvial sediments: U.S. Geological Survey OpenFile Report 93-125, $217 \mathrm{p}$.

Great Lakes Environmental Center, 2006, Development of a copper criteria adjustment procedure for Michigan's Upper Peninsula waters: accessed April 2, 2018, at http://www. michigan.gov/documents/deq/wrd-swas-ssR57-CuCriteria 484685 7.pdf.

Hoffman, P.F., 1988, United plates of America, the birth of a craton-Early Proterozoic assembly and growth of Laurentia: Annual Review of Earth Planetary Sciences, v. 16, no. 1, p. 543-603.

Homer, C.G., Dewitz, J.A., Yang, L., Jin, S., Danielson, P., Xian, G., Coulston, J., Herold, N.D., Wickham, J.D., and Megown, K., 2015, Completion of the 2011 National Land Cover Database for the conterminous United StatesRepresenting a decade of land cover change information: Photogrammetric Engineering and Remote Sensing, v. 81, no. 5 , p. $345-354$.

Hughes, J.D., and Merry, W.J., 1978, Marquette buried forest 9,850 years old in Abstract for 144th Annual Meeting, Washington, D.C. February 12-17, 1978: American Association for the Advancement of Science, $115 \mathrm{p}$.

Illinois State Geological Survey, 2009, Timetable of Quaternary glacial and interglacial events: accessed August 23, 2018, at http://www.isgs.illinois.edu/outreach/geologyresources/classification-quaternary-time-and-deposits.

MacDonald, D.D., Ingersoll, C.G., and Berger, T.A., 2000, Development and evaluation of consensus-based sediment quality guidelines for freshwater ecosystems: Archives of Environmental Contamination and Toxicology, v. 39, p. 20-31.

Maloney, T.J., ed., 2005, Quality management system, U.S. Geological Survey National Water Quality Laboratory: U.S. Geological Survey Open-File Report 2005-1263, version 1.3 , November 9, 2005, chapters and appendixes variously paged.
Mayer, A., Grubb, J, and Theimann, K, 2004, Assessment of hydrologic information concerning the Yellow Dog and Salmon-Trout Rivers watersheds, 23 p., accessed December 28, 2017, at http://citeseerx.ist.psu.edu/viewdoc/download? doi $=10.1 .1 .594 .8943 \&$ rep $=$ rep $1 \&$ type $=$ pdf.

McKay, L., Bondelid, T., Dewald, T., Johnston, J., Moore, R., and Rea, A., 2012, NHDPlus version 2-User guide: accessed September 27, 2018, at https://s3.amazonaws.com/ nhdplus/NHDPlusV21/Documentation/NHDPlusV2_User Guide.pdf .

Medalie, Laura, and Martin, J.D., 2017, Nutrient and pesticide contamination bias estimated from field blanks collected at surface-water sites in U.S. Geological Survey water-quality networks, 2002-12: U.S. Geological Survey Scientific Investigations Report 2016-5129, 40 p.

Michigan Department of Environmental Quality, 2006, Part 4-Water quality standards: accessed April 2, 2018, at http://www.michigan.gov/documents/deq/wrd-rulespart4_521508_7.pdf.

Michigan Department of Environmental Quality, 2018, Rule 57 water quality values: Michigan Department of Environmental Quality website, accessed April 2, 2018, at http://www.michigan.gov/deq/0,4561,7-1353313_3681_3686_3728-11383-,00.html.

Mueller, D.K., and Titus, C.J., 2005, Quality of nutrient data from streams and ground water sampled during water years 1992-2001: U.S. Geological Survey Scientific Investigations Report 2005-5106, 27 p.

National Oceanic and Atmospheric Administration, 2018, National Centers for Environmental Information Climate Data web page, accessed August 14, 2018, at https:// www.ncdc.noaa.gov/cdo-web/datasets/GHCND/stations/ GHCND:USC00200771/detail.

Newman, L.E, and R.B. DuBois, eds., 1996, Status of brook trout in Lake Superior: prepared for the Lake Superior Technical Committee by the Brook Trout Committee, accessed August 14, 2018, at http://www.thegreaterlakesuperiorfoundation.org/pdf/StatusOfBrookTroutInLakeSuperior.pdf.

Premo, D., Premo, K., and Premo, B., 2005, Baseline limnological studies of streams in the vicinity of a proposed sulfide mine in Marquette County, Michigan: White Water Associates, Inc., Report MI/DEQ/WB-05/029.

PRISM Climate Group, 2018, PRISM climate data: Northwest Alliance for Computational Science and Engineering, Oregon State University, accessed August 14, 2018, at http://prism.oregonstate.edu. 
Rantz, S.E., and others, 1982, Measurement and computation of streamflow_-Volume 2, computation and discharge: U.S. Geological Survey Water-Supply Paper 2175, 631 p.

Reed, R.C., and Daniels, Jennifer, comps., 1987, Bedrock geology of northern Michigan: Geological Survey Division, Michigan Department of Natural Resources, scale 1: 500,000 .

Senay, G.B., Bohms, Stefanie, Singh, R.K., Gowda, P.H., Velpuri, N.M., Alemu, Henok, Verdin, J.P., 2013, Operational evapotranspiration mapping using remote sensing and weather datasets - A new parameterization for the SSEB approach: Journal of the American Water Resources Association, v. 49, no. 3, p. 577-591, accessed August 14, 2018, at http://dx.doi.org/10.1111/jawr.12057.

Shreve, E.A., and Downs, A.C., 2005, Quality-assurance plan for the analysis of fluvial sediment by the U.S. Geological Survey Kentucky Water Science Center Sediment Laboratory: U.S. Geological Survey Open-File Report 2005-1230, $28 \mathrm{p}$.

Sims, P.K., and Peterman, Z.E., 1983, Evolution of Penokean foldbelt, Lake Superior region, and its tectonic environments, in Medaris, L.G., Jr., ed., Early Proterozoic geology of the Lake Superior region: Geological Society of America Memoir v. 160, p. 3-14.

Superior Watershed Partnership, 2007, Salmon Trout River Watershed Management Plan: accessed August 14, 2018, at http://www.michigan.gov/documents/deq/wb-nps-salmontrout-wmp_284714_7.pdf.

Turnipseed, D.P., and Sauer, V.B., 2010, Discharge measurements at gaging stations: U.S. Geological Survey Techniques and Methods book 3, chap. A8, 87 p.

Twenter, F.R, 1981, Geology and hydrology for environmental planning in Marquette County, Michigan: U.S. Geological Survey Water Resources Investigation 80-90, 44 p.
U.S. Department of Agriculture, 2007, Ottawa National Forest-Wild and scenic river comprehensive river management plan: U.S. Department of Agriculture, Forest Service Eastern Region, accessed August 14, 2018, at https://www. rivers.gov/documents/plans/ottawa-nf-plan.pdf.

U.S. Geological Survey, 2018, National Water Information System-Web interface, accessed April 25, 2018, at http:// dx.doi.org/10.5066/F7P55KJN.

U.S. Geological Survey, 2016, Guidance on annotating results affected by contamination bias, with examples for water samples affected by Co and Mn contamination from highcapacity capsule filters: U.S. Geological Survey Office of Water Quality Technical Memorandum 2016.05, accessed August 14, 2018, at https:/water.usgs.gov/admin/memo/ QW/qw2016.05.pdf.

U.S. Geological Survey, variously dated, National field manual for the collection of water-quality data: U.S. Geological Survey Techniques of Water-Resources Investigations, book 9, chaps. A1-A10, available online at https://pubs. water.usgs.gov/twri9A.

Van Schmus, W.R., and Woolsey, L.L., 1975, Rb-Sr geochronology of the Republic area, Marquette County, Michigan: Canadian Journal of Earth Science, v. 12, p. 1723-1733.

Weaver, T.L., Sullivan, D.J., Rachol, C.M., and Ellis, J.M., 2010, Water quality and hydrology of the Silver River Watershed, Baraga County, Michigan, 2005-08: U.S. Geological Survey Scientific Investigations Report 2010-5050, $66 \mathrm{p}$.

Williams, Teresa, Foreman, W.T., Decess, Jessica, ReedParker, Carmen, and Stevenson, D.L., 2015, Changes to National Water Quality Laboratory (NWQL) procedures used to establish and verify laboratory detection and reporting limits: U.S. Geological Survey National Water Quality Laboratory Technical Memorandum 15.02, accessed August 14, 2018, at http://wwwnwql.cr.usgs.gov/tech_memos/ nwq1.2015-02.pdf. 
For additional information contact:

Director, Upper Midwest Water Science Center U.S. Geological Survey

6520 Mercantile Way

Suite 5

Lansing, MI 48911

Publishing support provided by the

Madison Publishing Service Center 


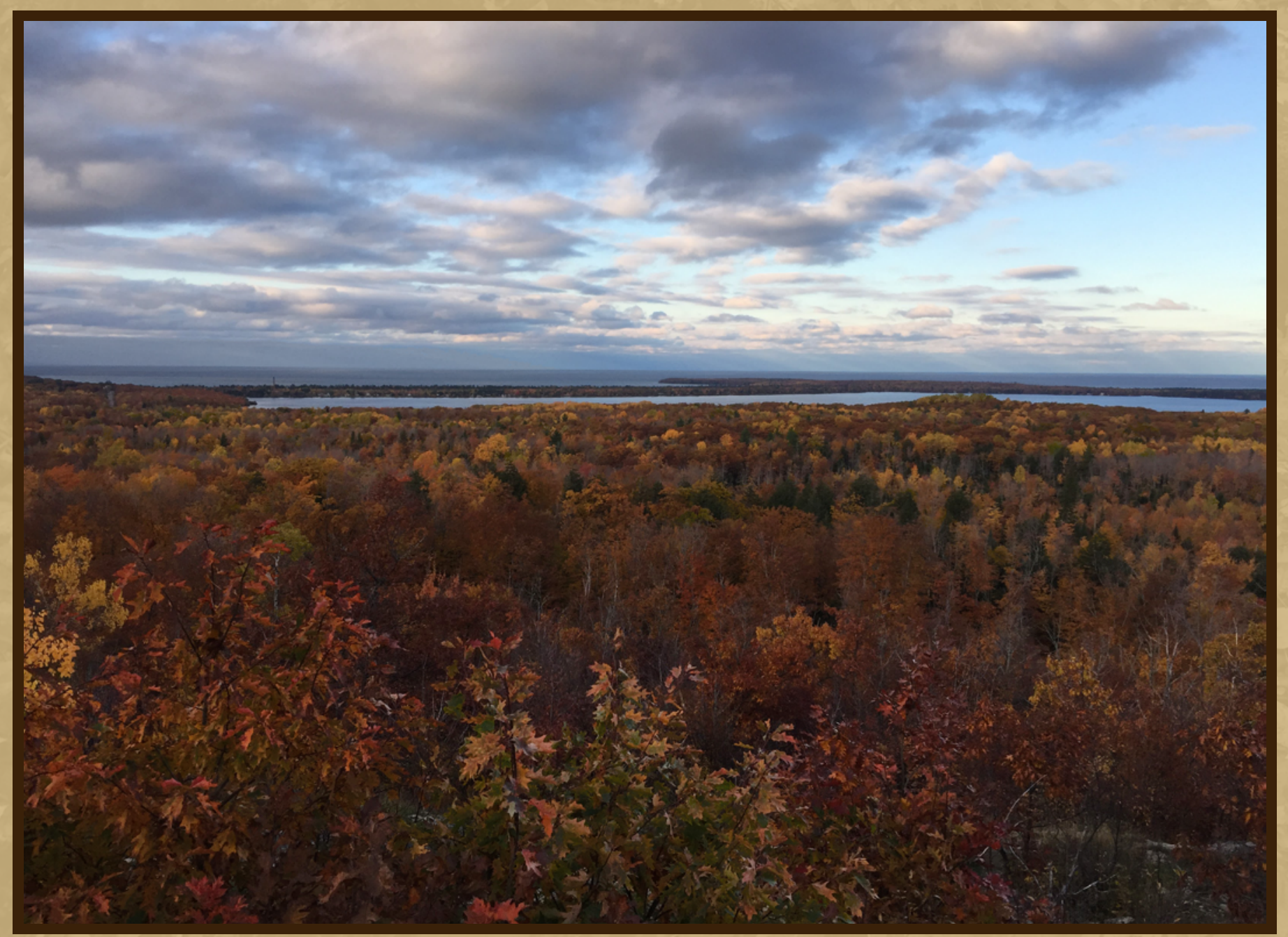

